\title{
Avifauna of the upper Purus River: relevant records for an area lacking ornithological surveys
}

\author{
Fernando Igor de Godoy ${ }^{1,5}$; Edson Guilherme ${ }^{2}$; Diego Pedroza ${ }^{3}$ \& Ricardo Antônio de Andrade Plácido ${ }^{4}$
}

1 Universidade Federal de São Carlos (UFSCAR), Centro de Ciências Biológicas e da Saúde (CCBS), Programa de Pós-Graduação em Ecologia e Recursos Naturais (PPGERN). São Carlos, SP, Brasil. ORCID: http://orcid.org/0000-0001-8406-4578. E-mail: fernando@casadafloresta.com.br

2 Universidade Federal do Acre (UFAC), Centro de Ciências Biológicas e da Natureza (CCBN), Laboratório de Ornitologia. Rio Branco, AC, Brasil. ORCID: http://orcid.org/0000-0001-8322-1770. E-mail: guilherme.edson@gmail.com

${ }^{3}$ Universidade Federal do Acre (UFAC), Centro de Ciências Biológicas e da Natureza (CCBN), Programa de Pós-Graduação em Ecologia e Manejo de Recursos Naturais (PPG-EMRN). Rio Branco, AC, Brasil. ORCID: http://orcid.org/0000-0003-3119-199X. E-mail: diego.guima1@hotmail.com

${ }^{4}$ Secretaria de Estado de Meio Ambiente (SEMA), Divisão de Áreas Naturais Protegidas e Biodiversidade. Rio Branco, AC, Brasil. ORCID: http://orcid.org/0000-0001-7021-8767. E-mail: ricardoplacido13@gmail.com

${ }^{5}$ Casa da Floresta Ambiental Ltda. Piracicaba, SP, Brasil.

\begin{abstract}
Birds are the best-known vertebrate group, although many localities in the world are considered to be knowledge gaps. This is the case of many little-known environments in the Amazon biome, the world's largest tropical forest. Here, we present a survey of birds in the upper Purus basin, comprising the municipalities of Manoel Urbano and Feijó in the Brazilian state of Acre, and Boca do Acre and Pauini in the state of Amazonas. In this region, poorly-studied habitats, such as open rainforest dominated by palms or bamboo, still predominate. We recorded 452 bird species during 45 field trips between May and July in 2016, and June to August in 2017. Twenty-four of these species are associated with bamboo habitat, 28 are endemic to the southwestern Amazon basin, and seven are threatened with extinction. This high diversity is typical of the western Amazon basin, one of the richest regions in the world in the number of species, due to the heterogeneity of the local environments. The data presented here highlight the importance of the region for the conservation of birds, including species typical of the western Amazon, some of which are still poorly-known.
\end{abstract}

Keywords. State of Acre; State of Amazonas; Bamboo habitat; Inambari endemism center.

\section{INTRODUCTION}

Birds are the best-known vertebrate group in terms of the identification of species, natural history, and geographic distribution (Silva, 2002; Del Hoyo et al., 2019). This is due to the relative ease of detection of these animals, typically without the need for capture, and the fact that birds occupy a wide range of niches in most environments around the world (Vielliard et al., 2010). Birds have raised human awareness since the time of ancient civilizations, which has also contributed to the accumulation of ornithological knowledge over the centuries. Today, amateur birdwatchers provide professional ornithologists with records as photographs and species lists on virtual platforms, adding to the knowledge of geographic distributions and seasonality (Greenwood, 2007; Bonney et al., 2009; Cottman-Fields et al., 2014; Mason, 1990; Sekercioglu, 2002; Sullivan et al., 2009; Horns et al., 2018). While birdwatching continues to grow, worldwide, and ornithological inventories have increased progressively in recent years, there are still several regions, especially remote areas, in need of detailed inventory of bird species.

Many locations in the Amazon still lack reliable inventories, especially in the most remote regions, for example, in mountainous regions or difficult to access (Oren \& Albuquerque, 1991; Laranjeiras et al., 2019). The existence of this knowledge gap has been reinforced in recent years by the descriptions of 15 new Amazonian species, such as Nystalus obamai and Hemitriccus cohnhafti, which is a quite unusual development for this otherwise well-documented group (Del Hoyo et al., 2013).

Due to the immense region and the difficulty of access in some places in the Amazon, the concentration of research has generally occurred close to urban centers (Cohn-Haft et al., 1997; Borges \& Guilherme, 2000; Guilherme, 2001; Vasconcelos et al., 2007) and on major rivers, such as the Amazon and Negro (Oren, 2001; Cohn-Haft et al., 2007; Borges et al., 2019). The avian fauna of the Amazon region is also quite heterogeneous, reflecting the diversity of habitats, with different flooding regimes and soil types (Braga, 
1979; Nelson \& Oliveira, 2001), as well as the existence of areas of endemism formed by large rivers that act as geographical barriers to dispersal (Hayes \& Sewlal, 2004; Silva et al., 2005; Silva \& Garda, 2010).

Since the beginning of the $20^{\text {th }}$ century, the many inventories conducted at remote localities of the basin of the Purus River, in southwestern Amazonia, have revealed an increasingly rich and heterogeneous avian fauna (Snethlage, 1908; Gyldenstolpe, 1951; O'neill, 1974; Buzzetti, 2010; Guilherme \& Dantas, 2011). These studies consisted of sporadic observations and systematic collection of hundreds of copies for museums. Despite the efforts mentioned, no ornithological survey was carried out in the border region of the states of Acre and Amazonas, in southwestern Brazilian Amazonia (Oren, 2001; Guilherme, 2016). Therefore, this study is a pioneer in the region, and in this way, we provide an inventory of the avian fauna of the upper Purus, which straddles the border of the Brazilian states of Acre and Amazonas.

\section{MATERIAL AND METHODS}

\section{Study area}

We conducted the study in areas that includes parts of the municipalities of Boca do Acre and Pauini, in the state of Amazonas, and Feijó and Manuel Urbano, in state of Acre (Fig. 1). These municipalities are located within the Inambari area of endemism, a zoogeographic region that is limited by the Amazon and Solimões rivers to the north, and the Madeira River to the east, and includes neighboring parts of the Peruvian and Bolivian Amazon (Haffer, 1978; Cracraft, 1985; Silva et al., 2019). We established a sample polygon within radius of $55 \mathrm{~km}$ ( 328,000 ha) from the intersection of the Purus River with the BR-364 federal highway in the municipality of Manoel Urbano, which was limited to the east by the left margin of the Purus $\left(08^{\circ} 45^{\prime} \mathrm{S}, 68^{\circ} 50^{\prime} \mathrm{W}\right)$ and west by BR-364 $\left(08^{\circ} 38^{\prime} \mathrm{S}, 68^{\circ} 48^{\prime} \mathrm{W}\right)$, with areas on the right margin of the river or to the south of the highway being dis-

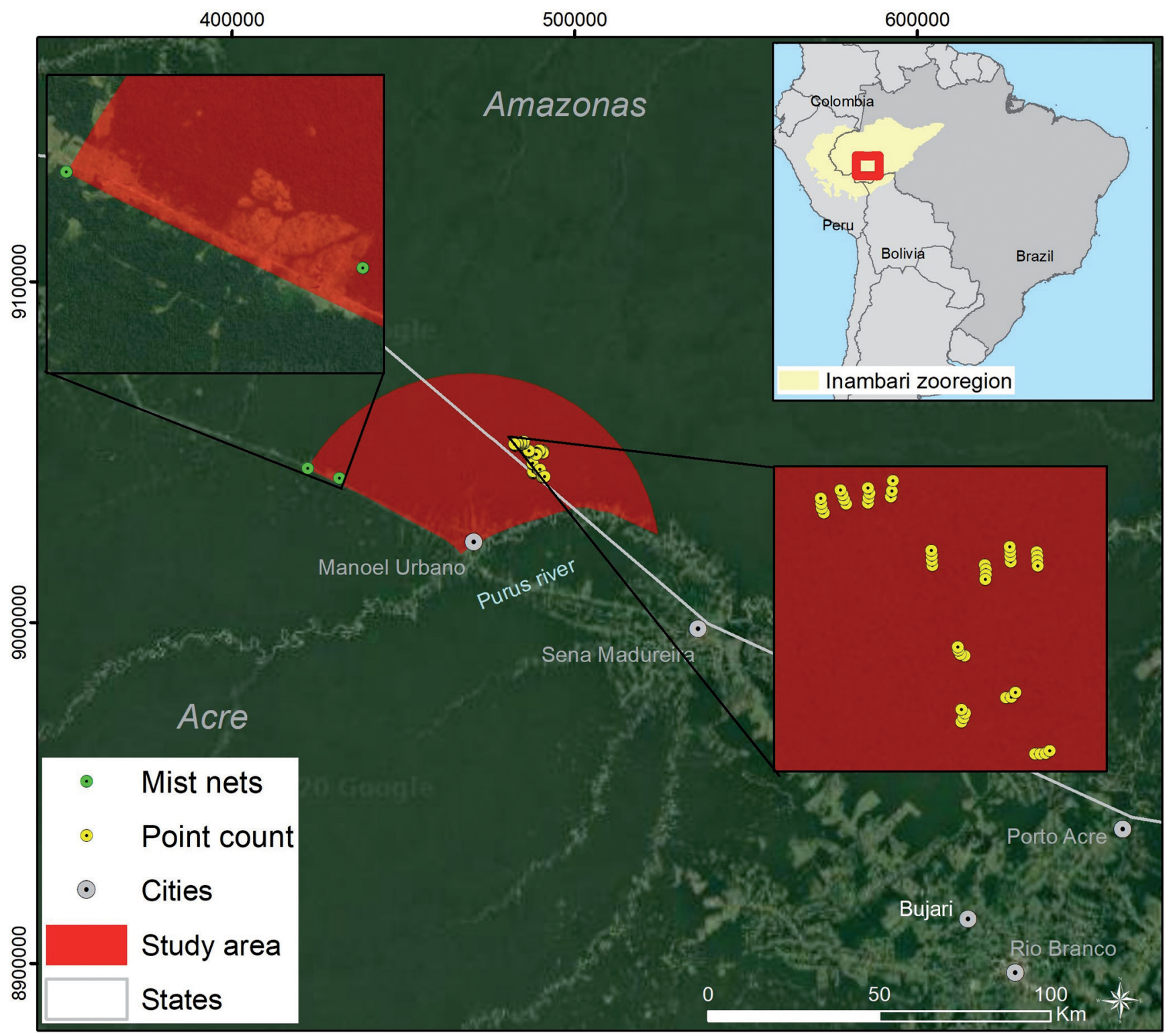

Figure 1. Study polygon, inserted in the zoogeographic zone of endemism Inambari (adapted from Silva et al., 2005, Google Earth credits). 
regarded (Fig. 1). The studied area comprises terra firme and várzea forest with bamboo and enclaves of forest with palms (Fig. 2) (Acre, 2000; IBGE, 2005; Guilherme, 2016).

\section{Survey period and sampling methods}

We conducted the research between the years 2016 and 2019 with opportunistic observations (photo and audio recordings) throughout this period, within the sampling polygon (Fig. 1). We obtained the opportunistic data through informal walks along the trails and the margin of the BR-364 highway, and motorboat surveys along stretches of the Purus River. In the eastern portion of the polygon, in May and July of 2016, and in June, July, and August of 2017, we used 48 points counts at 200-m intervals along 12 pre-established trails. The count lasted $15 \mathrm{~min}$ at each point. Twelve 1-km transects were also walked for 1 hour on average. We apply both procedures during the morning period, with four point counts and one transect being conducted per morning. We also record some species using playbacks, when there was a need for documentation or visualization, and we recorded audios with Tascam DR100 and Sony PX 820 recorders.

In September 2017, we sampled the western extreme of the polygon with $202.5 \mathrm{~m} \times 12 \mathrm{~m}$ mist-nets $(36 \mathrm{~mm}$ mesh). We placing the nets along two pre-established trails, covering an extension of $264 \mathrm{~m}$, during two days, and opened between 6:30 a.m. and 11:00 a.m. (Fig. 1). The birds we capture, we measure the: beak length, tarsus length, wing length, rectrix length using a digital caliper (precision $0.01 \mathrm{~mm}$ ), full length with ruler, and body mass with digital balance (precision of $0.1 \mathrm{~g}$ ), following the protocol of Proctor \& Lynch (1993). We collected some individuals for scientific collection and prepared them using the traditional taxidermy method. All specimens collected during fieldwork are now housed at Federal University of Acre (UFAC) in Rio Branco, Acre (Brazil). Specimens were captured under ICMBio/SISBIO authorization № 23269-1. We capture and collect the birds by the Comitê de Ética no Uso dos Animais - CEUA (Committee on Animal Research an Ethics) of the Universidade Federal do Acre under process 23107.008809/2016-62. We deposit photographic and audio records on either the WikiAves (WA) or the Fonoteca Casa da Floresta (FCF) online platforms. All the vouchers are referenced in the Appendix.

\section{Species classifications}

We classify species in: (1) food guilds, according to Wilman et al. (2014); (2) association with habitats dom-
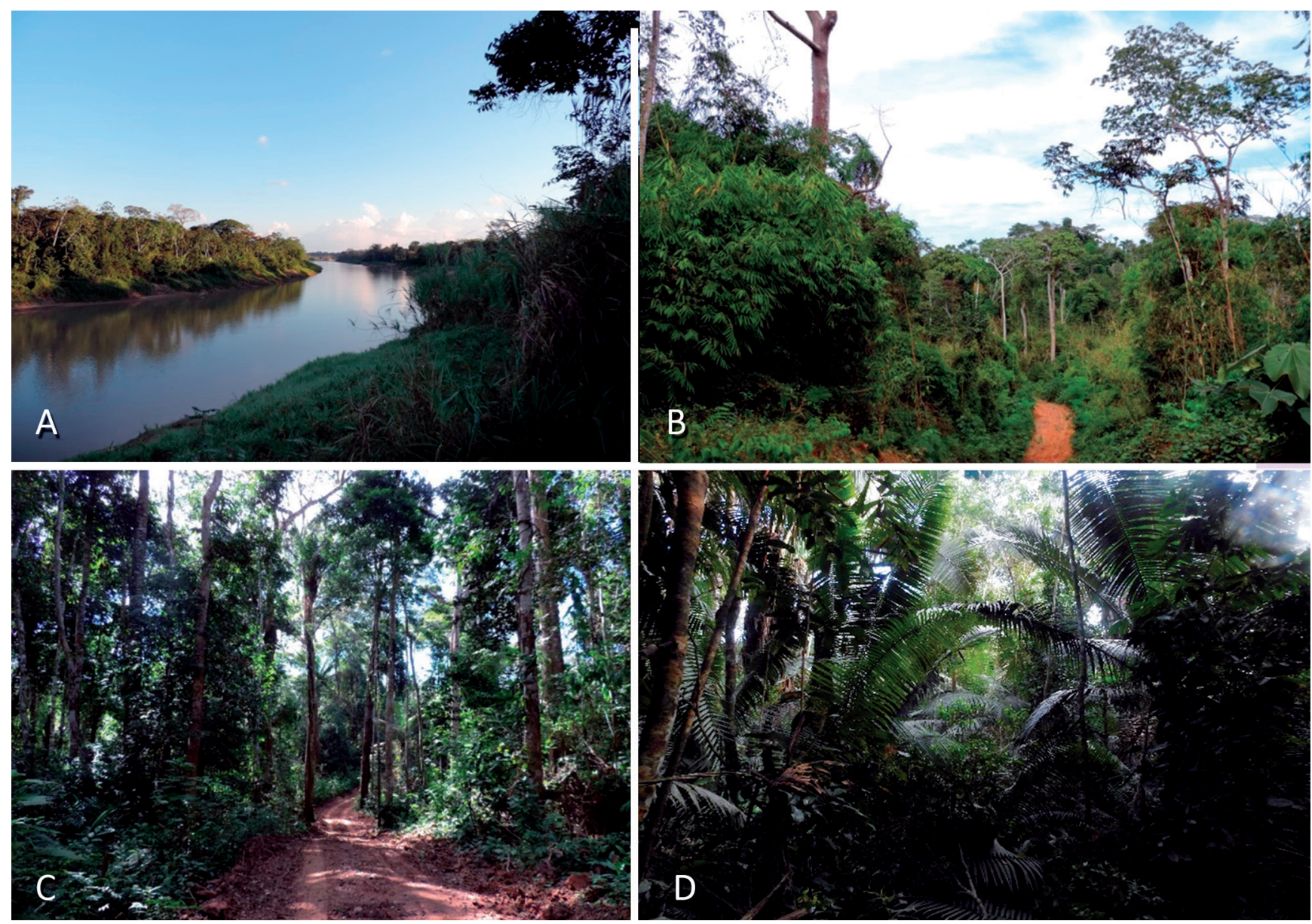

Figure 2. Phytophysiognomies of the study area: (A) várzea forest, upper Purus River, (B) terra firme forest with habitats dominated by bamboo, (C) terra firme forest with low bamboo and palms density (Photos: Diogo C. Casanova, Casa da Floresta collection) and (D) terra firme forest with habitats dominated by palms (Photo: Edson Guilherme). 
inated by bamboo Guadua ssp., according to Kratter (1997), Guilherme \& Santos (2009), Lebbin (2013) and Guilherme (2012, 2016); (3) endemism, considering the endemism center Inambari and Andes Foothills or southern Amazon, according to Haffer (1978), Cracraft (1985), Guilherme (2016) and Silva et al. (2019); (4) risk of extinction, according to Lista Nacional Oficial das Espécies da Fauna Ameaçadas de Extinção (Brasil, 2014) and Red List for Birds (IUCN, 2020); and (5) dependence on forest environment, being forest-dwelling species, forest generalists and non-forests (adapted from Parker III et al., 1996; Wilman et al., 2014). Scientific nomenclature follows that of the Comitê Brasileiro de Registros Ornitológicos (Piacentini et al., 2015).

\section{RESULTS}

We recorded a total of 452 bird species in 69 families and 26 orders (Appendix). The main food guilds we recorded were the insectivores (209 species), omnivores (99 species), and frugivores (55 species). Twenty-four of the species $(5.31 \%)$ are specialists or have some degree of association with bamboo habitat. Overall, 37 of the species (8.19\%) are considered to be endemic to the southern margin of the Solimões/Amazon River. Another even more restricted distribution classification refers to the Amazonian zoogeographic zones, with 28 (6.19\%) recorded taxa belonging to the Inambari and Andes Foothils. Regarding the categories of forest environments, the predominate of forest-dwelling species (69\%), followed by forest generalists (16\%) and non-forest (15\%). In addition, seven species we recorded are listed as vulnerable to extinction - Tinamus tao, Harpia harpyja, Morphnus guianensis, Patagioenas subvinacea, Ramphastos tucanus cuvieri, Ramphastos vitellinus culminatus, and Primolius couloni.

\section{Species accounts}

Crypturellus atrocapillus (Tschudi, 1844): It occurs in southeastern Peru, northern Bolivia and Brazil (Cabot et al., 2019), where it can be considered relatively common and with wide distribution (Aleixo \& Guilherme, 2010). In Brazil, represented by subspecies C. a. garleppi (Berlepsch, 1892), the species was exclusive to Acre (Guilherme, 2009), not appearing in the list of the MapiáInauini National Forest (Silva, 2009) and the Arapixi Extractive Reserve (Mendonça et al., 2010), both located in the municipalities of Boca do Acre and Pauini, in the Amazonas state. However, in the eastern portion of the sampled region, which includes the same municipalities, it was frequent, with records at several sampling points. These records are the first of the species for the Amazonas state, deposited in the WikiAves platform (WA2455992).

Morphnus guianensis (Daudin, 1800): species of wide occurrence in South and Central America, however rare in all its geographic distribution due to its low densi- ty and because it occupies preferably primary forests (Sanaiotti et al., 2018). An individual was photographed on August 14, 2017 (WA2669908) in the western portion of the study area, on the border between the municipalities of Feijó and Manoel Urbano, state of Acre.

Accipiter poliogaster (Temminck, 1824): although widely distributed throughout South America (FergusonLees \& Christie, 2006), in the region it seems to be uncommon, with records in Peru (Schulenberg et al., 2007), one record in Rondônia (WA3312535), and only one record in Acre known until then, the recording of an individual in the municipality of Xapuri by M. Melo and F.I. Godoy (Guilherme, 2016). We record an individual in the eastern portion, on July 6, 2016, in Manoel Urbano, state of Acre.

Laterallus fasciatus (Sclater \& Salvin, 1868): Rare Amazonian species with very few records in Brazil. Its distribution extends from Colombia to Peru and northwestern Brazil on the Solimões and Purus rivers, in the Western Amazon (Pinto, 1978; Del Hoyo et al., 1996; Sick, 1997). It's found in the riparian forest, dense undergrowth of humid forests and grassy areas including river islands (Schulenberg et al., 2007). Three couples are recorded on the Purus river bank in the region near the bridge over BR-364 in the municipality of Manoel Urbano, state of Acre.

Phaethornis bourcieri (Lesson, 1832): The species is distributed along the north bank of the Amazon River, extending along the Guianas Shield, Northwestern Brazil, Colombia, Ecuador and eastern Peru, reaching the Acre state (Hinkelmann et al., 2019). Although there are records in Acre territory (Guilherme, 2016), it appears to be more easily recorded through captures with nets than through observation. In the eastern portion of the study area, we record only one individual, on July 23, 2017, through his vocalization.

Chrysuronia oenone (Lesson, 1832): forest hummingbird that occur from Venezuela to Bolivia, with few records in western Brazil (Stiles \& Boesman, 2019). Guilherme (2016) mentions records for the species in Acre at Serra do Divisor and Juruá region. In our study the species was recorded in the eastern portion of the study area, foraging in semi-open areas over the years 2016 and 2017, both in portions in the municipality of Boca do Acre, Amazonas and Manoel Urbano, Acre. We were not able to document the species with photographs or soud recordings, however the birds were undoubtedly identified by the males plumage pattern with a contrasting blue on the head, general greenish plumage, and golden rump and rectrices (Schulenberg et al., 2007; Stiles \& Boesman, 2019). Our records represent an extension of distribution of $400 \mathrm{~km}$ eastwards for the species.

Heliodoxa aurescens (Gould, 1846): species with wide distribution in the Amazon biome, but considered uncommon (Parker III et al., 1996; Schulenberg et al., 2007). In the Inambari region in Brazilian territory, only two 
records are known for the Acre state, both on the border with Peru, one in the extreme west Acre (Guilherme, 2016), and the other in the extreme south (Aleixo \& Guilherme, 2010). Along our survey, three sightings were made in the eastern portion of the study area, two of which were on the same day (about $800 \mathrm{~m}$ apart), in a forest portion in which the species appears to be locally common.

Steatornis caripensis Humboldt, 1817: an individual was observed on the night of May 22, 2016, flying at about $3 \mathrm{~m}$ high along a road between the municipalities of Manoel Urbano, Acre and Boca do Acre, Amazonas. This nocturnal bird is associated with caves, where it remains at rest during the day, but during the night the bird can travel great distances in search of fruit (Cleere, 2010). Roca (1994) in a study in Venezuela, verified through telemetry that the species moved $240 \mathrm{~km}$ between caves in a single night. This would justify the presence of the species in the region, which has no documented cave environment. It is one of the most unusual records, because in Brazil the species was only known for two localities, both in the Amazonas state, in Manaus (WikiAves, 2008) and in Reserva Natural de Palmari (Whittaker et al., 2004), the latter being approximately $460 \mathrm{~km}$ away from our study site. In addition to northern Amazonia and Central America (Trinidad and Panama), S. caripensis distribution perimeter extends from Colombian Andes to Bolivia (Thomas \& Kirwan, 2019), with some records in the Ucayali and Loreto departments in Peru, bordering the Acre state (Tello et al., 2008), but $\sim 500 \mathrm{~km}$ away from the study area.

Pyrrhura rupicola (Tschudi, 1844): species endemic in the Inambari area, considered exclusive of the Acre state in the Brazilian territory (Aleixo \& Guilherme, 2010), with records only in the eastern and extreme western portions of Acre (Guilherme, 2016). It is one of the most common parrots in study area, both in the Acre and Amazon regions, recorded on almost every sampling day, with predominant records in slightly disturbed forest areas.

Forpus xanthopterygius (Spix, 1824): although widely distributed in South America, it has disjunct populations, and in the Amazon it is restricted to its western portion (Collar et al., 2019). Despite being quite common in northern and central Peru (Schulenberg et al., 2007), it appears to be rare in the Acre state, where there are only two records (Guilherme, 2016). A group of Forpus xanthopterygius was observed on $21^{\text {st }}$ July 2017 in the eastern portion of our study area.

Nannopsittaca dachilleae O'Neill, Munn \& Franke, 1991: little known species and of very restricted distribution, occurring only in northwestern Bolivia, eastern Peru and Brazil, exclusively in Acre state (Schulenberg et al., 2007; Guilherme, 2016; Collar \& Boesman, 2019). Despite sparse records in the Acre state (DeLuca, 2012), their documentation in Brazilian territory came from specimens collected in the region of Mâncio Lima (Guilherme,
2016). A group was photographed on July 21,2017 in the municipality of Pauini, constituting a new record for the Amazonas state, expanding its known distribution.

Celeus spectabilis Sclater \& Salvin, 1880: species associated with bamboo habitats (Kratter, 1997; Lebbin 2013; Guilherme, 2016), previously considered exclusive to the Acre state in Brazilian territory (Guilherme, 2009). It was recently recorded in Rondônia (Corrêa, 2013). The species was recorded throughout the entire polygon, which shows that it is relatively common in the region.

Antrostomus sericocaudatus (Cassin, 1849): It has two disjunct populations. Antrostomus sericocaudatus mengeli (Dickerman, 1975) occurs in southeastern Peru, northwestern Bolivia and Brazil, with sparse records throughout the Amazon, especially in the Acre state (Cleere, 2019). In Acre the species has been recorded only in the eastern portion of the state, on the right bank of the Purus River (Guilherme, 2016). Our records are the first for the left bank of the Purus River in Brazil. In the eastern portion, it proves to be relatively common, easily recorded through its vocalization.

Picumnus subtilis Stager, 1968: endemic species in the Andes Foothills and adjacent lowlands, recently recorded in Brazil (Rego et al., 2009). Considered restricted to the eastern portion of the Acre state, and associated with bamboo habitats (Melo et al., 2015; Guilherme, 2016). The species was common in the Manoel Urbano region, and our records are the first for the left bank of the Purus River in Brazil. Despite being considered associated with bamboo habitats (Guilherme, 2016), we recorded an individual in a secondary forest in the western portion in the municipality of Feijó (WA2849280), and a couple in semi-urban areas of Manoel Urbano (WA3726020), both records in the state of Acre. We do not rule out the possibility of expanding the species' distribution after the suppression (e.g., deforestation, agriculture) in the forest.

Grallaria eludens (Lowery \& O'Neill, 1969): one of the most poorly studied Amazonian bird species, it was known from few records imited to the border between Peru and Brazil (Krabbe \& Schulenberg, 2019a). There are only four records for Brazil, all in the extreme west of the states of Acre and Amazonas (Whittaker \& Oren, 1999; Guilherme, 2016). The species was recorded in the eastern portion of our study area in two occasions, on May $21^{\text {st }}$ and $24^{\text {th }}, 2016$. Although not seen, it was documented through the recording of the song. Our records represent an expansion of distribution of $400 \mathrm{~km}$ to the east, although recent records were made at Chandless State Park (WA2939664), about 100 km from our study site.

Formicarius rufifrons Blake, 1957: terrestrial bird restricted to a few localities in southwestern Peru, Bolivia and Brazil (Krabbe \& Schulenberg, 2019b). In Brazil, the species range is restricted to the Acre state, where there were four records in the extreme south and extreme west of the state (Guilherme, 2016). More recently, it 
was recorded about $50 \mathrm{~km}$ west of Rio Branco (Ramal do Noca) (Melo, 2016). During our survey, we record an individual in the eastern portion of the study site (FCF01683), on May 25, 2016, representing the first record for the Amazonas state. This record represents an extension of distribution of $\sim 200 \mathrm{~km}$ to the east.

Myrmotherula brachyura (Hermann, 1783): although widely distributed in the Amazon, in Acre the species was previously recorded exclusively in the border with Peru, in the extreme west of the state (Guilherme, 2016). However, along our survey, M. brachyura was quite common in the eastern portion of the study area.

Myrmotherula assimilis Pelzeln, 1868: species associated with várzea forests, present on the margins of the largest Amazonian rivers, such as Purus (Schulenberg et al., 2007). The first record in Acre territory comes from a vocalization recorded in 2001, by Jeremy Minns, in the Alto Juruá Extractive Reserve (XC237143). The first and only specimen from Acre was collected in the western portion of the polygon (AC-936), by EG and DP in terra firme forest on $16^{\text {th }}$ of August 2017, in the municipality of Feijó. The capture of this individual in terra firme forest reinforces the idea that the species can inhabit environments other than the várzea forest in this region of the Amazon.

Hypocnemis subflava Cabanis, 1873: Bamboo habitat specialist, with home range areas limited to bamboo patches of the genus Guadua spp. (Lebbin, 2013; Pedroza \& Guilherme, 2019). The species was common throughout the study area, both in the Acre state and in the Amazonas state. We did not record its counterpart $H$. peruviana along our survey, probably a case of local substitution.

Xenops rutilans Temminck, 1821: species with wide distribution in Brazil, but scarce in the Amazon, whose occurrence predominates in its southeast portion, where the taxon X. r. purusianus Todd, 1925 ranges from eastern Peru to the Tapajós River (Remsen, 2019). In Acre, is uncommon, with a predominance of records in the far west of the state (Guilherme, 2016). FIG recorded Xenops rutilans twice in the eastern portion of the study area (WA3484857).

Anabazenops dorsalis (Sclater \& Salvin, 1880): uncommon species, scarce in the Amazonian lowlands (Schulenberg et al., 2007). In Brazil there are occasional records in the states of Mato Grosso, Rondônia and Acre (Guilherme, 2016). Although difficult to visualize, the species was relatively common in the eastern portion of the study area, before the bamboo fruiting in 2016. Anabazenops dorsalis was not detected past the bamboo fruiting period. Our records represent the first records for the central region of Acre, and for the Amazonas state.

Synallaxis cherriei Gyldenstolpe, 1930: poorly known species, considered rare, but can be locally common.
In the Inambari region, it has restrict distribution (Schulenberg et al., 2007; IUCN, 2020), with few known records, possibly of the subspecies S. c. saturata Carriker, 1934 (Guilherme, 2016). The records presented here are the first for the center of the Acre state and for the Amazonas state. We record the species in the eastern portion on two occasions, always in dense shrub formations at the edge of the forest.

Lepidothrix coronata (Spix, 1825): Two subspecies are recognized for the region of Inambari, L. C. coronata (Spix, 1825 ) to the west of the Purus River and L. coronata exquisita (Hellmayr, 1905) to the east, with a clear difference in plumage from the males (Guilherme, 2016). However, all records of the species were auditory, making it impossible to confirm which taxon occurs in the study area, believing that it corroborates with that described for the region.

Pachyramphus xanthogenys Salvadori \& Festa, 1898: species considered exclusive to the Acre state in Brazil, where it was thought to occur only in the eastern portion of the state (Guilherme, 2016). One individual was recorded in the Amazonas state, municipality of Boca do Acre, extending the distribution of the species at $\sim 200 \mathrm{~km}$ northwest.

Conioptilon mcilhennyi Lowery \& O'Neill, 1966: species of distribution restricted to Peru, Bolivia and Brazil, where it was recorded exclusively in the Acre state (Guilherme, 2009; Guilherme, 2012). In our study sites, the species was fairly common, with records in almost all sites that had large trees, including sites in the Amazonas state.

Cotinga maynana (Linnaeus, 1766): a little documented species for the region and also uncommon in the study area. We recorded the bird twice in the eastern portion of the study area. Three males was observed on $25^{\text {th }}$ July 2017. We photographed one individual (WA2960588) and we recorded its wing flap sounds (FCF02224).

Porphyrolaema porphyrolaema (Deville \& Sclater, 1852): species with few documented records for Brazil. In the Acre state was known only from two localities (Guilherme, 2016). On 24 ${ }^{\text {th }}$ June 2017, FIG observed and photographed a couple birds on the eastern portion of our study area (WA2960587).

Hemitriccus iohannis (Snethlage, 1907): in Brazilian territory, $H$. iohannis was thought to occur only on the western and eastern portions of the Acre state (Guilherme, 2016), being virtually absent in the Purus River region. Along our 2016 surveys, few individuals were occasionally recorded in Manoel Urbano, in the riparian forest of the Purus River (FCF01692).

Muscisaxicola fluviatilis Sclater \& Salvin, 1866: uncommon species of open environments, such as sand banks on river edge (Schulenberg et al., 2007). There 
were only two records for the Acre state (Guilherme, 2016). We record an individual in the western portion in a deforested area covered by pioneer vegetation on the edge of BR-364. We collect this individual a voucher specimen (AC-948) and deposited in the UFAC ornithological collection.

Conopias trivirgatus (Wied, 1831): species with few records around the study area, in the Acre state they are concentrated on the border with Peru (Guilherme, 2016). The closest area to our study site where the bird was recorded before was the State Park Chandless (Buzzetti, 2009). We record the species three times at different points in the eastern portion of our study area (FCF02141).

Sublegatus obscurior Todd, 1920: species of forest edge and semi-open environments, rare in the region, with only one record in the Acre state (Guilherme, 2016). We record one individual along our survey, by the road side at the edge of a high-density bamboo forest, in Manoel Urbano (Acre), on May 20, 2016 (WA2445534).

Polioptila plumbea (Gmelin, 1788): although this species has a wide distribution in South America (Atwood et al., 2019), the subspecies that occur in the region, P. p. parvirostris Sharpe, 1885 appears to be uncommon, with few records in southeastern Peru (southern limit of taxon distribution) (Harvey et al., 2014) and in the Acre state, with only three records (Guilherme, 2016). However, in our study area it was locally common in almost all the extension of the eastern portion, always in the forest canopy of terra firme forest.

Parkerthraustes humeralis (Lawrence, 1867): uncommon species in the region, with only two previous records for the Acre state (Whittaker et al., 2002; Buzzetti, 2009). A group of three individuals was observed and photographed foraging in the canopy of terra firme forest in the eastern portion of the study area, on July 21 , 2017.

\section{DISCUSSION}

The high bird species richness recorded along our survey is related primarily to the location of the study area, given that the Amazon Forest is the world's biologically richest region (Boubli \& Hrbek, 2012), and that the Inambari center of endemism is one of its richest in bird species (Hawkins et al., 2006). This region is also dominated by tracts of climax primary forest, which supports many birds typical of preserved environments, which occupy the different forest strata (canopy, medium, litter, understory, and edge), with a high level of landscape connectivity. There is also an ample diversity of environments, with the forest bird community including terra firme and várzea forest, and specialists in bamboo habitats, although a majority of the species are strict forest species. This group includes many species that depend on well-preserved forest and are sensitive to environmental change (Parker III et al., 1996). These species include the threatened Harpia harpyja and Tinamus tao, which are associated with large tracts of mature forest, disappearing rapidly from fragmented habitats and areas with intense hunting pressure (ICMBio, 2018).

The dominant vegetation of the study area, bamboo forest, is quite distinct from the typical Amazonian dense forest formations, with a continuous canopy, and shady understory. Thirty Amazonian bird species are recognized as bamboo habitat specialists (Guilherme \& Santos, 2009; Harvey et al., 2014), and the 24 were present in the study area. The association of insectivorous birds with bamboo habitat may guarantee the avoidance of competition with similar species for feeding resources and nest-building materials, such as insectivorous birds of dense edge shrub formations and understory (e.g., Thamnophilidae, Rhynchocyclidae, Furnariidae) (Lebbin, 2007; Pedroza \& Guilherme, 2019). In addition, granivorous species such as the Amazonian Parrotlet (Nannopsittaca dachilleae) and the Slate-colored Seedeater (Sporophila schistacea) appear to accompany the fruiting of Guadua bamboo, to feed on its seeds (Collar \& Boesman, 2019).

The fruiting of the bamboo may have a major impact on the structure of bird communities given that, following this event, the bamboo suffers massive mortality, provoking profound changes in local environments (Areta \& Cockle, 2012). Following the die off of the bamboo, there is an abrupt increase in the penetration of sunlight into the previously shaded understory, and an associated increase in temperature, with the whole stratum disappearing until the development of the new seedlings. Photophobic species of the leaf litter, such as the Elusive Antpitta (Grallaria eludens) and the Thrushlike Antpitta (Myrmothera campanisona), were absent from the sampling sites following the bamboo fruiting. By contrast, birds associated with clearings such as the Thrush-like Wren (Campylorhynchus turdinus) and the Olived-faced Flatbill (Tolmomyias flaviventris viridiceps) increased in abundance. Following the die off, bird species associated with bamboo stands became extremely scarce, which was expected - see Areta \& Cockle (2012). Habitat fragmentation may also limit the displacement or dispersal of these exclusively forest-dwelling species, which may be limited by the availability of native forest. Furthermore, many other specialist taxa forage in bamboo habitat, which means that it determines an important component of the biodiversity of the forest communities (Guilherme \& Santos, 2009).

The local avian fauna also includes a number of species typical of open environments, such as aquatic habitats (Purus River and local streams), roads, and other anthropogenic environments. In fact, a number of species that did not occur originally in the region, such as the Burrowing Owl (Athene cunicularia) and the White-tailed Hawk (Geranoaetus albicaudatus), have benefitted from the human colonization process, which has resulted in widespread deforestation, principally for the implantation of cattle pasture. The relatively recent phenomenon has become increasingly frequent throughout 
the region, and with the spread of deforestation (Souza et al., 2006), bird species adapted to open habitats have become progressively more widespread in the Amazon biome (Guilherme \& Czaban, 2015).

The vast majority of the bird taxa that are endemic to the Inambari center of endemism were recorded in the area of the present study (Guilherme, 2016). The Purus River also appears to play a role as a zoogeographic barrier, dividing the ranges of Lepidothrix coronata coronata and L. C. exquisita, for example (Guilherme, 2009; Guilherme, 2012). However, three taxa considered by Guilherme (2012) to be restricted to the right margin of the Purus were recorded on the left margin in the present study, Antrostomus sericocaudatus, Picumnus subtilis and Xiphorhynchus chunchotambo, which implies that this river may not be a very effective zoogeographic barrier for many taxa (Guilherme, 2016).

The dynamics of the annual flooding, which inundates a number of parts of the local forest, also influences the composition of the local bird community (Haugaasen \& Peres, 2008), reinforcing the need to evaluate the response of the community, especially given the potential shifts in resource availability. Further research may include additional sampling procedures, including more systematic surveys along the seasonally flooded areas.

Overall, then, our results reinforce the need for further research in the Inambari center of endemism, in particular, in the central and western portions of Amazonas state. We would also recommend further research on the open bamboo habitats at other sites in southwestern Amazonia, in order to better understand the relationship between bamboo specialists and bamboo habitat. As most research in the Amazon basin has tended to focus on dense rainforest habitats (Barlow et al., 2007), the bamboo habitats of southwestern Amazonia is relatively poorly-understood. Further research is clearly needed to better understand the dynamics of the influence of the bamboo cycle on the local avian fauna and its occurrence patterns over the long term, as well as providing important insights for the development of effective conservation measures.

\section{CONCLUSIONS}

The presence of threatened species and the high level of endemism found at the study site reinforces the ecological importance of the studied area and the need for its conservation. While the eastern portion of the Acre state, in the vicinity of the capital, Rio Branco, is the most deforested (Guilherme, 2016), the study region, which is located further west is also now beginning to suffer the effects of these impacts. Deforestation in the study region was initially limited to the occupation of areas along rivers and roads by smallholders, although it has accelerated in recent years, mainly through highway construction and the expansion of cattle ranching operations. This implies that the region of the upper Purus River may resemble the east of the state of Acre, in terms of habitat fragmentation, which will increase the risk of the local extinction of many of the species recorded in the present study that are sensitive to environmental impacts.

\section{ACKNOWLEDGMENTS}

F.I.G. thanks the support of Arthur Macarrão, Diogo C. Casanova, Marcelo Ducatti, Vagner Gabriel, Rodrigo Bernando (layout), Barbara R. Barbosa (layout) and Lys Pereira de Souza. We are grateful to Agrocortex Madeiras do Acre. E.G. and D.P. would like to thank TECMAN - consultoria ambiental e manejo florestal and Secretaria de Meio Ambiente do Estado do Acre - SEMA for the logistical support during this study. We also thank the UFAC Ornithology Laboratory team for the preparation and cataloging of the collected specimens. We are grateful to prof. Stephen Ferrari for suggestions and English translation.

\section{AUTHORS' CONTRIBUTIONS}

F.I.G. and E.G. conceived of the presented idea including the design and implementation of the research. F.I.G., E.G., D.P. and R.A.A.P. conducted the fieldwork. F.I.G. compiled and tabulated the data. All authors contributed to the analysis of the results and to the writing of the manuscript. All authors review and approve the final version of the paper.

\section{REFERENCES}

A Enciclopédia das Aves do Brasil (WikiAves). 2008. Wiki Aves - A Enciclopédia das Aves do Brasil. Available: http://www.wikiaves.com.br. Access: 05/03/2020.

Acre, Governo do Estado. 2000. Programa estadual de Zoneamento EcológicoEconômico do estado do Acre. Rio Branco, SECTMA.

Aleixo, A. \& Guilherme, E. 2010. Avifauna da Estação Ecológica do Rio Acre, estado do Acre, na fronteira Brasil/Peru: composição, distribuição ecológica e registros relevantes Avifauna of the Estação Ecológica do Rio Acre, state of Acre, on the Brazil/Peru border: composition. Boletim do Museu Paraense Emilio Goeldi: Ciências Naturais, 5(3): 279-309.

Areta, J.I. \& Cockle, K.L. 2012. A theoretical framework for understanding the ecology and conservation of bamboo-specialist birds. Journal of Ornithology, 153(Suppl. 1): 163-170.

Atwood, J.; Lerman, S. \& Kirwan, G.M. 2019. Tropical Gnatcatcher (Polioptila plumbea). In: Del Hoyo, J.; Elliott, A.; Sargatal, J.; Christie, D.A. \& De Juana, E. (Eds.). Handbook of the Birds of the World Alive. Barcelona, Lynx Edicions,. Available: https://www.hbw.com/node/58986. Access: 25/09/2019.

Barlow, J.; Mestre, L.A.M.; Gardner, T.A. \& Peres, C.A. 2007. The value of primary, secondary and plantation forests for Amazonian birds. Biological Conservation, 136(2): 212-231.

Bonney, R.; Cooper, C.B.; Dickinson, J.; Kelling, S.; Phillips, T.; Rosenberg, K.V. \& Shirk, J. 2009. Citizen science: a developing tool for expanding science knowledge and scientific literacy. BioScience, 59(11): 977-984.

Borges, S.H. \& Guilherme, E. 2000. Comunidade de aves em um fragmento florestal urbano em Manaus, Amazonas, Brasil. Ararajuba, 8: 17-23. 
Borges, S.H.; Baccaro, F;; Moreira, M. \& Choueri, E.L. 2019. Bird assemblages on Amazonian river islands: Patterns of species diversity and composition. Biotropica, 51: 1-10.

Boubli, J.P.\& Hrbek, T. 2012. Introdução à biodiversidade amazônica. In:Marcon, J.L.; Menin, M.; Araújo, M.G.P. \& Hrbek, T. (Eds.). Biodiversidade Amazônica: caracterização, ecologia e conservação. Manaus, EDUA. p. 11-18.

Braga, P.I.S. 1979. Subdivisão fitogeográfica, tipos de vegetação, conservação e inventário florístico da floresta amazônica. Acta amazonica, 9: 53-80.

Brasil. 2014. Portaria № 444, de 17 de dezembro de 2014. Lista Nacional Oficial das Espécies da Fauna Ameaçadas de Extinção. Diário Oficial da União, Brasília, DF, № 245, seção 1, p. 121-126.

Buzzetti, D. 2009. Avaliação Ecológica Rápida para a Elaboração do Plano de Manejo do Parque Estadual Chandless, Estado do Acre - Relatório Técnico Final do Componente Avifauna. SOS Amazônia e SEMA - Secretaria de Estado do Meio Ambiente do Acre (Relatório Técnico Não Publicado).

Buzzetti, D. 2010. Avifauna. In: Brilhante, S.H.C. (Ed.). Plano de Manejo do Parque Estadual Chandless. SOS Amazônia. p. 3.111-3.121.

Cabot, J.; Christie, D.A.; Jutglar, F.; Boesman, P. \& Sharpe, C.J. 2019. Blackcapped Tinamou (Crypturellus atrocapillus). In: Del Hoyo, J.; Elliott, A.; Sargatal, J.; Christie, D.A. \& De Juana, E. (Eds.). Handbook of the Birds of the World Alive. Barcelona, Lynx Edicions. Available: https://www.hbw. com/node. Access: 25/09/2019.

Cleere, N. 2010. Nightjars, Potoos, Frogmouths, Oilbird, and Owlet-nightjars of the World. Hampshire, Princeton University Press.

Cleere, N. 2019. Silky-tailed Nightjar (Antrostomus sericocaudatus). In: Del Hoyo, J.; Elliott, A.; Sargatal, J.; Christie, D.A. \& De Juana, E. (Eds.). Handbook of the Birds of the World Alive. Barcelona, Lynx Edicions. Available: https://www.hbw.com/node/55191. Access: 25/09/2019.

Cohn-Haft, M.; Naka, L.N. \& Fernandes, A.M. 2007. Padrões de distribuição da avifauna da várzea dos rios Solimões e Amazonas. In: Albernaz, A.L. (Eds.). Conservação da várzea: identificação e caracterização de regiões biogeográficas. Manaus, Ibama/ProVárzea. p. 287-323.

Cohn-Haft, M.; Whittaker, A. \& Stouffer, P.C. 1997. A new look at the "species-poor" central Amazon: the avifauna north of Manaus, Brazil. Ornithological Monographs, 48: 205-235.

Collar, N. \& Boesman, P. 2019. Amazonian Parrotlet (Nannopsittaca dachilleae). In: Del Hoyo, J.; Elliott, A.; Sargatal, J.; Christie, D.A. \& De Juana, E. (Eds.). Handbook of the Birds of the World Alive. Lynx Edicions, Barcelona. Available: https://www.hbw.com/node/54700. Access: 25/09/2019.

Collar, N.; Kirwan, G.M. \& Boesman, P. 2019. Blue-winged Parrotlet (Forpus xanthopterygius). In: Del Hoyo, J.; Elliott, A.; Sargatal, J.; Christie, D.A. \& De Juana, E. (Eds.). Handbook of the Birds of the World Alive. Barcelona, Lynx Edicions. Available: https://www.hbw.com/node/54686. Access: 25/09/2019.

Corrêa, A.G. 2013. [WA1901281, Celeus spectabilis Sclater \& Salvin, 1880]. Wiki Aves - A Enciclopédia das Aves do Brasil. Available: http://www. wikiaves.com/1901281. Access: 09/03/2020.

Cottman-Fields, M.; Brereton, M.; Wimmer, J. \& Roe, P. 2014. Collaborative extension of biodiversity monitoring protocols in the bird watching community. In: Participatory Design Conference on Short Papers, Industry Cases, Workshop Descriptions, Doctoral Consortium papers, and Keynote. 13․ Abstracts. PDC 14. New York, ACM Press. v. 2, p. 111-114.

Cracraft, J. 1985. Historical biogeography and patterns of differentiation within the South American avifauna: areas of endemism. Ornithological Monographs, 36: 49-84.

Del Hoyo, J.; Elliott, A. \& Sargatal, J. (Eds.). 1996. Handbook of the birds of the world. Hoatzin to Auks. Barcelona, Lynx Edicions.

Del Hoyo, J.; Elliott, A.; Sargatal, J. \& Christi, D.A. 2013. Handbook of the Birds of the World, Special Volume: New Species and Global Index. Barcelona, Lynx Edicions.
Del Hoyo, J.; Elliott, A.; Sargatal, J.; Christie, D.A. \& De Juana, E. (Eds.). 2019. Handbook of the Birds of the World Alive. Barcelona, Lynx Edicions. Available: https://www.hbw.com/node. Access: 25/09/2019.

DeLuca, J.J. 2012. Birds of conservation concern in eastern Acre, Brazil: distributional records, occupancy estimates, human-caused mortality, and opportunities for ecotourism. Tropical Conservation Science, 5(3): 301-319.

Ferguson-Lees, J. \& Christie, D.A. 2006. Raptors of the World. London, Princeton University Press.

Greenwood, J.J.D. 2007. Citizens, science and bird conservation. Journal of Ornithology, 148: 77-124.

Guilherme, E. 2001. Comunidade de aves do Campus e Parque Zoobotanico da Universidade Federal do Acre, Brasil. Tangara, 1: 57-73.

Guilherme, E. 2009. Avifauna do estado do Acre: composição, distribuição geográfica e conservação. (Doctoral Thesis). Universidade Federal do Pará, Museu Paraense Emílio Goeldi, Belém.

Guilherme, E. 2012. Birds of the Brazilian state of Acre: Diversity, zoogeography, and conservation. Revista Brasileira de Ornitologia, 20(4): 393-442.

Guilherme, E. 2016. Aves do Acre. Rio Branco, Editora da Universidade Federal do Acre.

Guilherme, E. \& Czaban, R.E. 2015. First record of the Yellowish Pipit in Acre with notes on other grassland birds in southwestern Amazônia. Neotropical Biology and Conservation, 10: 169-176.

Guilherme, E. \& Dantas, S.M. 2011. Avifauna of the Upper Purus River, State of Acre, Brazil. Revista Brasileira de Ornitologia, 19(2): 185-1999.

Guilherme, E. \& Santos, M.P.D. 2009. Birds associated with bamboo forests in eastern Acre, Brazil. Bulletin of the British Ornithologists' Club, 129(4): $229-240$.

Gyldenstolpe, N. 1951. The ornithology of the Rio Purus region in western Brazil. Arkiv für Zoologi, 2: 1-320.

Haffer, J. 1978. Distribution of Amazon forest birds. Bonner Zoologische Beiträge, 29: 38-78.

Harvey, M.G.; Lane, D.F.; Hite, J.; Terrill, R.S.; Ramírez, S.F.; Smith, T.; Klicka, J. \& Campos, W.V. 2014. Notes on bird species in bamboo in northern Madre de Dios, Peru including the first Peruvian record of Acre Tody-Tyrant (Hemitriccus cohnhafti). Occasional Papers of the Museum of Natural Science, Lousiana State University, 81: 1-38.

Haugaasen, T. \& Peres, C.A. 2008. Population abundance and biomass of large-bodied birds in Amazonian flooded and unflooded forests. Bird Conservation International, 18: 87-101.

Hawkins, B.A.; Diniz-Filho, J.A.F.; Jaramillo, C.A. \& Soeller, S.A. 2006. PostEocene climate change, niche conservatism, and the latitudinal diversity gradient of New World birds. Journal of Biogeography, 33(5): 770-780.

Hayes, F.E. \& Sewlal, J.A.N. 2004. The Amazon River as a dispersal barrier to passerine birds: effects of river width, habitat and taxonomy. Journal of Biogeography, 31(11): 1809-1818.

Hinkelmann, C.; Kirwan, G.M. \& Boesman, P. 2019. Straight-billed Hermit (Phaethornis bourcieri). In: Del Hoyo, J.; Elliott, A.; Sargatal, J.; Christie, D.A. \& De Juana, E. (Eds.). Handbook of the Birds of the World Alive. Barcelona, Lynx Edicions,. Available: https://www.hbw.com/ node/55364. Access: 25/09/2019.

Horns, J.J.; Adler, F.R. \& Şekercioğlu, Ç.H. 2018. Using opportunistic citizen science data to estimate avian population trends. Biological Conservation, 221: $151-159$

Instituto Brasileiro de Geografia e Estatística (IBGE). 2005. Potencial Florestal do estado do Acre. Rio de Janeiro, Instituto Brasileiro de Geografia e Estatística.

Instituto Chico Mendes de Conservação da Biodiversidade (ICMBio). 2018. Livro Vermelho da Fauna Brasileira Ameaçada de Extinção. Brasília, ICMBio/MMA 
International Union for Conservation of Nature and Natural Resources (IUCN). 2020. BirdLife International: Red List for Birds. Available: http://www. birdlife.org. Access: 01/03/2020.

Krabbe, N.K. \& Schulenberg, T.S. 2019a. Elusive Antpitta (Grallaria eludens). In: Del Hoyo, J.; Elliott, A.; Sargatal, J.; Christie, D.A. \& De Juana, E. (Eds.). Handbook of the Birds of the World Alive. Barcelona. Lynx Edicions. Available: https://www.hbw.com/node/56907. Access: 25/09/2019.

Krabbe, N.K. \& Schulenberg, T.S. 2019b. Rufous-fronted Antthrush (Formicarius rufifrons) In: Del Hoyo, J.; Elliott, A.; Sargatal, J.; Christie, D.A. \& De Juana, E. (Eds.). Handbook of the Birds of the World Alive. Barcelona, Lynx Edicions. Available: https://www.hbw.com/node/56863. Access: 25/09/2019.

Kratter, A. 1997. Bamboo specialization by Amazonian birds. Biotropica, 29: 100-110.

Laranjeiras, T.0.; Melinski, R.D.; Naka, L.N.; Leite, G.A.; Lima, G.R.; d'AffonsecaNeto, J.A. \& Cohn-Haft, M. 2019. Three bird species new to Brazil from the Serra da Mocidade, a remote mountain in Roraima. Revista Brasileira de Ornitologia, 27(4): 275-283.

Lebbin, D.J. 2007. Habitat specialization among Amazonian birds: why are there so many Guadua bamboo specialists? (Masters Dissertation). New York, Cornell University.

Lebbin, D.J. 2013. Nestedness and patch size of Bamboo-specialist bird communities in southeastern Peru: anidamiento y tamaño de parche en comunidades de aves especialistas de Bambú en el sudeste de Perú. The Condor, 115(2): 230-236.

Mason, C.F. 1990. Assessing population trends of scarce birds using information in a county bird report and archive. Biological Conservation, 52(4): 303-320.

Melo, T.N. 2016. Rapid Ecological Assessment of the birds on the upper Jurupari. Atualidades Ornitológicas, 189: 10-15.

Melo, T.N.; Olmos, F. \& Quental, J. 2015. New records of Picumnus subtilis (Aves: Picidae), Cnipodectes superrufus and Hemitriccus cohnhafti (Aves: Rhynchocyclidae) in Acre, Brazil. Check List, 11: 1-4.

Mendonça, F.C.; Narahara, K.L. \& Vasconcelos, V.0. (Org.). 2010. Plano de Manejo Participativo da Reserva Extrativista Arapixi. Instituto Boca do Acre, Chico Mendes de Conservação da Biodiversidade - ICMBio.

Nelson, B.W. \& Oliveira, A. 2001. Estado do conhecimento florístico da Amazônia. In: Capobianco, J.P.R.; Veríssimo, A.; Moreira, A.; Sawer, D.; Ikeda, S. \& Pinto, L.P. (Eds.). Biodiversidade na Amazônia Brasileira: avaliação e ações prioritárias para a conservação, uso sustentável e repartição de benefícios. São Paulo, Estação Liberdade e Instituto Socioambiental. p. 132-182.

O'neill, J.P. 1974. the birds of Balta, a peruvian dry tropical forest locality, with an analysis of their origins and ecological relationships. LSU Historical Dissertations and Theses, 2626: 1-284.

Oren, D.C. 2001. Biogeografia e conservação de aves na região Amazônica. In: Capobianco, J.P.R.; Veríssimo, A.; Moreira, A.; Sawer, D.; Ikeda, S. \& Pinto, L.P. (Eds.). Biodiversidade na Amazônia brasileira: avaliação de ações prioritárias para a conservação, uso sustentável e repartição de benefícios. Estação São Paulo, Liberdade e Instituto Socioambiental. p. 97-109.

Oren, D.C. \& Albuquerque, H.G. 1991. Priority areas for new avian collections in Brazilian Amazônia. Goeldiana Zoologia, 6: 1-11.

Parker III, T.A.; Stotz, D.F. \& Fitzpatrick, J.W. 1996. Ecological and distributional databases for neotropical birds. Chicago, The University Chicago Press.

Pedroza, D. \& Guilherme, E. 2019. Home range, population density, and foraging behaviour of the Yellow-breasted Warbling-Antbird (Hypocnemis subflava) in forest fragments in southwestern Brazilian Amazonia. Journal of Natural History, 53(31-32): 1905-1922.

Piacentini, V.Q.; Aleixo, A.; Agne, C.A.; Maurício, G.N.; Pacheco, J.F.; Bravo, G.A.; Brito, G.R.R.; Naka, I N.; Olmos, F.; Posso, S.; Silveira, L.F.; Betini, G.S.;
Carrano, E.; Franz, I.; Lees, A.L.; Lima, L.M.; Pioli, D.; Schunck, F.; Amaral, F.R.; Bencke, G.A.; Cohn-Haft, M.; Figueiredo, L.F.A.; Straube, G.C. \& Cesari, E. 2015. Annotated checklist of the birds of Brazil by the Brazilian Ornithological Records Committee/Lista comentada das aves do Brasil pelo Comitê Brasileiro de Registros Ornitológicos. Revista Brasileira de Ornitologia, 23(2): 91-298.

Pinto, 0.M.0. 1978. Novo Catálogo das Aves do Brasil. Primeira Parte. Aves não Passeriformes e Passeriformes não Oscines, com exclusão da Família Tyrannidae. São Paulo, Empresa Gráfica Revista dos Tribunais.

Proctor, N.S. \& Lynch, P.J. 1993. Manual of Ornithology. Avian structure and function. New Haven, Yale University Press.

Rego, M.R.; Dantas, S. de M.; Guilherme, E. \& Martuscelli, P. 2009. First records of Fine-barred Piculet Picumnus subtilis from Acre, western Amazonia, Brazil. Bulletin of the British Ornithologists' Club, 129(3): 182-185.

Remsen, J.V. 2019. Streaked Xenops (Xenops rutilus) In: Del Hoyo, J.; Elliott, A.; Sargatal, J.; Christie, D.A. \& De Juana, E. (Eds.). Handbook of the Birds of the World Alive. Barcelona, Lynx Edicions. Available: https://www.hbw. com/node/56591. Access: 25/09/2019.

Roca, R.L. 1994. Oilbirds of Venezuela: Ecology and conservation. Publications of Nuttall Ornithological Club, 24: 1-83

Sanaiotti, M.; Banhos, Á.; Aguiar-Silva, F.H.; Martins, F.D.; Luz, B.B. da, Carvalho, A.S. \& Ruiz, C.M. 2018. Morphnus guianensis (Daudin, 1800). In: ICMBio/MMA. Livro Vermelho da Fauna Brasileira Ameaçada de Extinção. Brasília,ICMBio/MMA. p. 121-124.

Schulenberg, T.S.; Stotz, D.F.; Lane, D.F.; O'neill, J.P. \& Parker III, T.A. 2007. Birds of Peru. New Jersey, Princeton University Press.

Sekercioglu, C.H. 2002. Impacts of birdwatching on human and avian communities. Environmental Conservation, 29(3): 282-289.

Sick, H. 1997. Ornitologia Brasileira. Rio de Janeiro, Editora Nova Fronteira.

Silva, J.M.C. 2002. Caatinga. In: Maury, C.M. (Ed.). Biodiversidade Brasileira. Brasília, Ministério do Meio Ambiente - Secretaria de Biodiversidade e Florestas. p. 133-174.

Silva, J.M.C. \& Garda, A.A. 2010. Padrões e processos biogeográficos na Amazônia. In: Carvalho, C.J.B. \& Almeida, E.A.B. (Eds.). Biogeografia da América do Sul: padrões e processos. São Paulo, Roca. p. 189-197.

Silva, J.M.C.; Rylands, A.B. \& Fonseca, G.A.B. 2005. The fate of the Amazonian areas of endemism. Conservation Biology, 19(3): 689-694.

Silva, S.M.; Peterson, A.T.; Carneiro, L.; Burlamaqui, T.C.T.; Ribas, C.C.; SousaNeves, T.; Miranda, L.S.; Fernandes A.M.; d'Horta, F.M.; Araújo-Silva, L.E.; Batista, R.; Bandeira, C.H.M.M.; Dantas, S.M.; Ferreira, M.; Martins, D.M.; Oliveira, J.; Rocha, T.C.; Sardelli, C.H.; Thom, G.; Rêgo, P.S.; Santos, M.P.; Sequeira, F.; Vallinoto, M. \& Aleixo A. 2019. A dynamic continental moisture gradient drove Amazonian bird diversification. Science Advances, 5(7): 1-11, eaat5752.

Silva, S.S. (Org.). 2009. Plano de manejo da Floresta Nacional Mapiá-Inauini. Boca do Acre, IBAMA/Floresta Nacional Mapiá-Inauini.

Snethlage, E. 1908. Eine Vogelsammlung vom Rio Purús, Brasilien. Journal für Ornithologie, 56: 7-24.

Souza, C.J.; Veríssimo, A.; Costa, A.S.; Reis, R.S.; Balieiro, C. \& Ribeiro, J. 2006. Dinâmica do desmatamento no Estado do Acre (1988-2004). Belém, IMAZON.

Stiles, F.G. \& Boesman, P. 2019. Golden-tailed Sapphire (Chrysuronia oenone). In: Del Hoyo, J.; Elliott, A.; Sargatal, J.; Christie, D.A. \& De Juana, E. (Eds.). Handbook of the Birds of the World Alive. Barcelona, Lynx Edicions. Available: https://www.hbw.com/node/55473. Access: 25/09/2019.

Sullivan, B.L.; Wood, C.L.; lliff, M.J.; Bonney, R.E.; Fink, D. \& Kelling, S. 2009. eBird: a citizen-based bird observation network in the biological sciences. Biological Conservation, 142(10): 2282-2292.

Tello, N.S.; Stojan-Dolar, M. \& Heymann, E.W. 2008. A sight and video record of the oilbird, Steatornis caripensis, in Peruvian lowland Amazonia. Journal of Ornithology, 149(2): 267-269. 
Thomas, B.T. \& Kirwan, G.M. 2019. Oilbird (Steatornis caripensis). In: Del Hoyo, J.; Elliott, A.; Sargatal, J.; Christie, D.A. \& De Juana, E. (Eds.). Handbook of the Birds of the World Alive. Barcelona, Lynx Edicions. Available: https:// www.hbw.com/node/55131. Access: 25/09/2019.

Vasconcelos, M.F.; Pacheco, J.F. \& Parrini, R. 2007. Levantamento e conservação da avifauna na zona urbana de Marabá. Cotinga, 28: 45-52.

Vielliard, J.M.E.; Almeida, M.E.C.; Anjos, L. \& Silva, W.R. 2010. Levantamento quantitativo por pontos de escuta e o Índice Pontual de Abundância (IPA). In: Matter, S.V.; Straube, F.C.; Accordi, I.A.; Piacentini, V.Q. \& Cândido-Jr., J.F. (Eds.). Ornitologia e Conservação - Ciência Aplicada, técnicas de pesquisa e levantamento. Rio de Janeiro, Technical Books. p. 47-60.

Whittaker, A. \& Oren, D.C. 1999. Important ornithological records from the Rio Juruá, western Amazonia, including twelve additions to the Brazilian. Bulletin of the British Ornithological Club, 119(4): 235-260.
Whittaker, A.; Antoine-Feill, S.A.H. \& Scheiele Z, R. 2004. First confirmed record of Oilbird Steatornis caripensis for Brazil. Bulletin of the British Ornithological Club, 124(2): 106-108.

Whittaker, A.; Oren, D.C.; Pacheco, J.F.; Parrini, R. \& Minns, J.C. 2002. Aves registradas na Reserva extrativista do Alto Juruá. In: Cunha, M.C. \& Almeida, M.B. (Eds.). Enciclopédia da Floresta. 0 Alto Juruá: práticas e conhecimentos das populações. São Paulo, Companhia das Letras. p. 81-99.

Wilman, H.; Belmaker, J.; Simpson, J.; De La Rosa, C.; Rivadeneira, M.M. \& Jetz, W. 2014. EltonTraits 1.0: Species-level foraging attributes of the world's birds and mammals. Ecology, 95(7): Data Papers 2027. DOI 


\section{APPENDIX}

List of bird species recorded in the study area, belonging to the region of the upper Purus River. Voucher: $\mathrm{FCF}=$ recording deposited at Fonoteca Casa da Floresta; WA = image or recording deposited on the WikiAves website; $\mathrm{AC}=$ specimen collected and deposited in the collection of the Ornithology Museum of the Federal University of Acre. ${ }^{1}$ Nomenclature and taxonomy follow CBRO (2015). ${ }^{2}$ Forest dependence: $\mathrm{FS}=$ forest-dwelling species; $\mathrm{FG}=$ forest generalists; $\mathrm{NF}=$ non-forests. ${ }^{3}$ Feeding guilds: $\mathrm{O}=$ omnivorous; $\mathrm{G}=$ gramnivorous, $\mathrm{F}=$ frugivores; $\mathrm{C}=$ carnivores, $\mathrm{S}=$ scavengers; $\mathrm{I}=$ insectivores; $\mathrm{M}=$ malacophagous; $\mathrm{P}=$ piscivores; $\mathrm{H}=$ herbivores; $\mathrm{N}=$ nectarivorous. ${ }^{4}$ Bamboo specialists. ${ }^{5}$ Endemic species of Inambari center (Inamb), Andes Foothils (AF) or South Amazonia (AMS). ${ }^{6}$ Endangered species at nacional (BR) or global level (G). ${ }^{7}$ Voucher (documentations): WA = Wiki Aves (photography); FCF = Fonoteca Casa da Floresta (audio recording). ${ }^{8}$ Recording type: $\mathrm{O}=$ visual observation; $\mathrm{V}=$ vocalization; $\mathrm{C}=$ specimen collected; $\mathrm{MN}=$ mist net. Municipality: $\mathrm{BA}=\mathrm{Boca}$ do Acre (AM); PA = Pauni (AM); MU = Manoel Urbano (AC); FE = Feió (AC).

\begin{tabular}{|c|c|c|c|c|c|c|c|c|c|}
\hline \multirow{2}{*}{ Families } & \multirow{2}{*}{ Species' } & \multirow{2}{*}{ Dep $^{2}$ Guild ${ }^{3}$} & \multirow{2}{*}{ Bamboo ${ }^{4}$} & \multirow{2}{*}{ Endemism ${ }^{5}$} & \multicolumn{2}{|c|}{ Red list $^{6}$} & \multirow{2}{*}{ Voucher' } & \multirow{2}{*}{ Rercording $^{8}$} & \multirow{2}{*}{ Municipality } \\
\hline & & & & & BR & G & & & \\
\hline \multirow[t]{10}{*}{ Tinamidae } & Crypturellus atrocapillus & FS & 0 & AMS (AF) & & NT & FCF01662, WA2455992 & $0, \mathrm{~V}$ & $\mathrm{BA}, \mathrm{PA}, \mathrm{MU}, \mathrm{FE}$ \\
\hline & Crypturellus bartletti & FS & 0 & AMS (Inamb) & & & FCF01663 & V & $\mathrm{BA}, \mathrm{MU}$ \\
\hline & Crypturellus cinereus & FS & 0 & & & & FCF01665 & V & $B A, P A, F E$ \\
\hline & Crypturellus obsoletus & FS & 0 & & & & FCF02143 & V & $\mathrm{BA}, \mathrm{FE}$ \\
\hline & Crypturellus soui & FS & 0 & & & & FCF02144 & V & $\mathrm{BA}, \mathrm{FE}$ \\
\hline & Crypturellus undulatus & FS & 0 & & & & & V & $\mathrm{BA}, \mathrm{MU}, \mathrm{FE}$ \\
\hline & Crypturellus variegatus & FS & 0 & & & & & V & $B A$ \\
\hline & Tinamus guttatus & FS & 0 & & & NT & FCF01765 & V & $B A, P A$ \\
\hline & Tinamus major & FS & 0 & & & NT & WA3717225 & $0, V$ & $\mathrm{BA}, \mathrm{FE}$ \\
\hline & Tinamus tao & FS & 0 & & VU & VU & FCF02260, FCF02261, WA3717226 & $0, \mathrm{~V}$ & BA \\
\hline Anhimidae & Anhima cornuta & $\mathrm{NF}$ & 0 & & & & & 0 & MU \\
\hline Anatidae & Amazonetta brasiliensis & $\mathrm{NF}$ & $P$ & & & & & 0 & $\mathrm{MU}, \mathrm{FE}$ \\
\hline \multirow[t]{4}{*}{ Cracidae } & Aburria cumanensis & FS & $\mathrm{F}$ & & & & WA2965224 & 0 & $\mathrm{BA}$ \\
\hline & Ortalis guttata & $\mathrm{FG}$ & $\mathrm{F}$ & & & & WA2968821 & $0, \mathrm{~V}$ & $\mathrm{BA}, \mathrm{MU}, \mathrm{FE}$ \\
\hline & Pauxi tuberosa & FS & 0 & & & & WA2969460 & 0 & BA \\
\hline & Penelope jacquacu & FS & 0 & & & & & $0, \mathrm{~V}$ & $B A, P A$ \\
\hline Odontophoridae & Odontophorus stellatus & FS & 0 & & & & WA3717224 & $0, v$ & $\mathrm{BA}, \mathrm{FE}$ \\
\hline Podicipedidae & Tachybaptus dominicus & $\mathrm{NF}$ & $P$ & & & & WA2669959 & 0 & $\mathrm{FE}$ \\
\hline Ciconiidae & Mycteria americana & $\mathrm{NF}$ & p & & & & WA2446772 & 0 & $B A, M U, F E$ \\
\hline Anhingidae & Anhinga anhinga & $\mathrm{NF}$ & $P$ & & & & & 0 & $\mathrm{FE}$ \\
\hline Phalacrocoracidae & Nannopterum brasilianus & $\mathrm{NF}$ & p & & & & & 0 & $B A$ \\
\hline \multirow[t]{7}{*}{ Ardeidae } & Ardea alba & $\mathrm{NF}$ & $\mathrm{P}$ & & & & & 0 & $\mathrm{BA}, \mathrm{MU}, \mathrm{FE}$ \\
\hline & Ardea cocoi & $\mathrm{NF}$ & $\mathrm{P}$ & & & & & 0 & $\mathrm{BA}, \mathrm{MU}$ \\
\hline & Bubulcusibis & $\mathrm{NF}$ & I & & & & & 0 & $\mathrm{BA}, \mathrm{MU}, \mathrm{FE}$ \\
\hline & Butorides striata & $\mathrm{NF}$ & $P$ & & & & & 0 & BA \\
\hline & Egretta thula & $\mathrm{NF}$ & $\mathrm{P}$ & & & & & 0 & $\mathrm{BA}, \mathrm{FE}$ \\
\hline & Pilherodius pileatus & $\mathrm{NF}$ & $\mathrm{P}$ & & & & WA2453561 & $0, \mathrm{~V}$ & $\mathrm{BA}, \mathrm{FE}$ \\
\hline & Tigrisoma lineatum & FG & $P$ & & & & & 0 & $B A, M U, F E$ \\
\hline Threskiornithidae & Mesembrinibis cayennensis & $\mathrm{NF}$ & M & & & & & 0 & MU \\
\hline \multirow[t]{4}{*}{ Cathartidae } & Cathartes aura & $\mathrm{NF}$ & s & & & & & 0 & $B A, M U, F E$ \\
\hline & Cathartes melambrotus & FS & s & & & & WA2968926 & $0, \mathrm{~V}$ & $B A, M U, F E$ \\
\hline & Coragyps atratus & $\mathrm{NF}$ & s & & & & & 0 & $\mathrm{BA}, \mathrm{MU}, \mathrm{PA}, \mathrm{FE}$ \\
\hline & Sarcoramphus papa & FG & S & & NT & & & 0 & $\mathrm{BA}, \mathrm{PA}$ \\
\hline \multirow[t]{12}{*}{ Accipitridae } & Accipiter poliogaster & FS & c & & DD & NT & & $0, \mathrm{~V}$ & MU \\
\hline & Accipiter superciliosus & FS & $c$ & & & & & 0 & $\mathrm{BA}$ \\
\hline & Busarellus nigricollis & FG & M & & & & & 0 & MU \\
\hline & Buteo albonotatus & $\mathrm{NF}$ & $c$ & & & & & 0 & $\mathrm{BA}, \mathrm{MU}$ \\
\hline & Buteo brachyurus & $\mathrm{FG}$ & $c$ & & & & & 0 & BA \\
\hline & Buteo nitidus & $\mathrm{FG}$ & $c$ & & & & & $0, V$ & $B A, M U, F E$ \\
\hline & Buteogallus schistaceus & FS & $c$ & & & & FCF02217/WA2580203 & $0, v$ & $\mathrm{BA}, \mathrm{MU}$ \\
\hline & Elanoides forficatus & $\mathrm{NF}$ & $c$ & & & & & 0 & $\mathrm{BA}, \mathrm{FE}$ \\
\hline & Geranoaetus albicaudatus & $\mathrm{NF}$ & $c$ & & & & & 0 & MU \\
\hline & Geranospiza caerulescens & $\mathrm{FG}$ & $c$ & & & & & 0 & BA \\
\hline & Harpagus bidentatus & FS & $c$ & & & & WA2966608 & $0, \mathrm{~V}$ & $\mathrm{BA}, \mathrm{FE}$ \\
\hline & Ictinia plumbea & $\mathrm{FG}$ & $c$ & & & & & $0, V$ & $\mathrm{BA}, \mathrm{FE}$ \\
\hline
\end{tabular}




\begin{tabular}{|c|c|c|c|c|c|c|c|c|c|c|}
\hline \multirow{2}{*}{ Families } & \multirow{2}{*}{ Species $^{1}$} & \multirow{2}{*}{$\operatorname{Dep}^{2}$} & \multirow{2}{*}{ Guild $^{3}$} & \multirow{2}{*}{ Bamboo $^{4}$} & \multirow{2}{*}{ Endemism $^{5}$} & \multicolumn{2}{|c|}{ Red list $^{6}$} & \multirow{2}{*}{ Voucher $^{7}$} & \multirow{2}{*}{ Rercording $^{8}$} & \multirow{2}{*}{ Municipality } \\
\hline & & & & & & BR & G & & & \\
\hline & Leptodon cayanensis & FS & $C$ & & & & & FCF02235 & $0, V$ & BA \\
\hline & Pseudastur albicollis & FS & $C$ & & & & & WA2455990 & 0 & $\mathrm{BA}$ \\
\hline & Rostrhamus sociabilis & NF & M & & & & & & 0 & $\mathrm{BA}$ \\
\hline & Harpia harpyja & FS & $C$ & & & VU & NT & & 0 & $\mathrm{MU}$ \\
\hline & Helicolestes hamatus & FS & M & & & & & WA2904859 & 0 & MU, FE \\
\hline & Rupornis magnirostris & $\mathrm{NF}$ & $C$ & & & & & FCF01752 & $0, V$ & $\mathrm{BA}, \mathrm{MU}, \mathrm{FE}$ \\
\hline & Urubitinga urubitinga & FG & 0 & & & & & WA1683501 & V & MU \\
\hline & Morphnus guianensis & FS & $C$ & & & VU & NT & & 0 & $\mathrm{FE}$ \\
\hline & Spizaetus melanoleucus & FS & $C$ & & & & & & 0 & BA \\
\hline & Spizaetus tyrannus & FS & $C$ & & & & & & $0, \mathrm{~V}$ & $\mathrm{BA}$ \\
\hline Eurypygidae & Eurypyga helias & FS & $C$ & & & & & FCF02229 & $0, \mathrm{~V}$ & MU \\
\hline Psophiidae & Psophia leucoptera & FS & 0 & & AMS (Inamb) & & NT & FCF02252, WA3717231 & $0, V$ & $\mathrm{BA}, \mathrm{MU}, \mathrm{FE}$ \\
\hline \multirow[t]{6}{*}{ Rallidae } & Aramides cajaneus & FG & 0 & & & & & & V & BA, FE \\
\hline & Laterallus melanophaius & FG & 0 & & & & & WA2671711 & $0, V$ & $\mathrm{FE}$ \\
\hline & Laterallus exilis & $\mathrm{NF}$ & 0 & & & & & & V & $\mathrm{FE}$ \\
\hline & Laterallus fasciatus & NF & 0 & & & & $\mathrm{LC}$ & WA2939709, WA3082943 & $0, V$ & MU \\
\hline & Porphyrio martinicus & NF & 0 & & & & & & 0 & $\mathrm{FE}$ \\
\hline & Laterallus viridis & FG & 0 & & & & & & V & $\mathrm{BA}$ \\
\hline \multirow[t]{2}{*}{ Charadriidae } & Vanellus cayanus & NF & 1 & & & & & WA2446767 & 0 & $B A, M U$ \\
\hline & Vanellus chilensis & $\mathrm{NF}$ & 1 & & & & & & $0, V$ & $\mathrm{BA}, \mathrm{MU}, \mathrm{FE}$ \\
\hline Jacanidae & Jacana jacana & $\mathrm{NF}$ & 0 & & & & & & $0, \mathrm{~V}$ & $\mathrm{BA}, \mathrm{FE}$ \\
\hline \multirow[t]{2}{*}{ Sternidae } & Phaetusa simplex & NF & $P$ & & & & & WA2455973 & 0 & BA \\
\hline & Sternula superciliaris & NF & $P$ & & & & & WA3355908 & 0 & $\mathrm{BA}, \mathrm{MU}$ \\
\hline Scolopacidae & Calidris fuscicollis & NF & M & & & & & & 0 & MU \\
\hline & Calidris melanotos & NF & M & & & & & & 0 & MU \\
\hline & Tringa solitaria & NF & M & & & & & WA2671698 & 0 & $\mathrm{FE}$ \\
\hline Rynchopidae & Rynchops niger & NF & $P$ & & & & & WA3355912 & 0 & $\mathrm{BA}, \mathrm{MU}$ \\
\hline Columbidae & Columbina talpacoti & NF & G & & & & & & $0, V$ & $\mathrm{BA}, \mathrm{MU}, \mathrm{FE}$ \\
\hline & Leptotila rufaxilla & FS & $\mathrm{F}$ & & & & & FCF02159, FCF02207 & V & $\mathrm{BA}, \mathrm{FE}$ \\
\hline & Leptotila verreauxi & FG & $\mathrm{F}$ & & & & & & V & $\mathrm{BA}, \mathrm{PA}, \mathrm{FE}$ \\
\hline & Geotrygon montana & FS & $\mathrm{F}$ & & & & & & $\mathrm{MN}$ & FE \\
\hline & Patagioenas plumbea & FS & $\mathrm{F}$ & & & & & WA2445561 & $0, V$ & $B A, P A$ \\
\hline & Patagioenas subvinacea & FS & $\mathrm{F}$ & & & & VU & FCF01731 & $0, V$ & $\mathrm{BA}, \mathrm{PA}, \mathrm{FE}$ \\
\hline Opisthocomidae & Opisthocomus hoazin & FS & Fo & & & & & WA2446768/WA2474281 & $0, V$ & $\mathrm{BA}, \mathrm{MU}, \mathrm{FE}$ \\
\hline Cuculidae & Coccycua minuta & FS & 1 & & & & & FCF02692 & V & $\mathrm{BA}$ \\
\hline & Coccyzus melacoryphus & FG & 1 & & & & & & $0, V$ & $B A$ \\
\hline & Crotophaga ani & $\mathrm{NF}$ & 1 & & & & & & $0, V$ & $\mathrm{BA}, \mathrm{MU}, \mathrm{FE}$ \\
\hline & Crotophaga major & FG & 1 & & & & & & 0 & $\mathrm{FE}$ \\
\hline & Dromococcyx pavoninus & FS & 1 & $x$ & & & & FCF02226 & V & $\mathrm{BA}$ \\
\hline & Dromococcyx phasianellus & FS & 1 & & & & & FCF02227 & V & BA \\
\hline & Piaya cayana & FG & I & & & & & & $0, V$ & $\mathrm{BA}, \mathrm{MU}, \mathrm{PA}, \mathrm{FE}$ \\
\hline & Piaya melanogaster & FS & 1 & & & & & FCF01736 & V & BA \\
\hline Strigidae & Athene cunicularia & $\mathrm{NF}$ & $C$ & & & & & WA2968819 & 0 & $\mathrm{BA}, \mathrm{MU}$ \\
\hline & Glaucidium brasilianum & FG & $C$ & & & & & & $0, V$ & BA \\
\hline & Tyto furcata & NF & $C$ & & & & & & 0 & $\mathrm{FE}$ \\
\hline & Asio clamator & NF & $C$ & & & & & & 0 & $\mathrm{FE}$ \\
\hline & Glaucidium hardyi & FS & C & & & & & & V & $B A$ \\
\hline & Lophostrix cristata & FS & $C$ & & & & & WA3484853 & $0, V$ & $\mathrm{BA}$ \\
\hline & Megascops usta & FS & $C$ & & & & & FCF02237 & $0, V$ & $B A$ \\
\hline Nyctibiidae & Nyctibius aethereus & FS & 1 & & & & & FCF02175, WA2967595 & $0, V$ & MU \\
\hline & Nyctibius grandis & FG & 1 & & & & & WA2973499 & $0, V$ & $\mathrm{BA}, \mathrm{MU}$ \\
\hline & Nyctibius griseus & FG & 1 & & & & & & $0, \mathrm{~V}$ & $\mathrm{BA}, \mathrm{FE}$ \\
\hline Steatornithidae & Steatornis caripensis & FS & $\mathrm{F}$ & & & & & & 0 & $\mathrm{MU}$ \\
\hline Caprimulgidae & Antrostomus sericocaudatus & FS & 1 & & & & & FCF02214 & $0, V$ & $\mathrm{BA}, \mathrm{MU}$ \\
\hline & Chordeiles rupestris & NF & 1 & & & & & & 0 & MU \\
\hline & Hydropsalis climacocerca & FG & 1 & & & & & & 0 & $\mathrm{BA}$ \\
\hline & Hydropsalis parvula & NF & 1 & & & & & & V & $\mathrm{BA}, \mathrm{FE}$ \\
\hline & Lurocalis semitorquatus & FS & I & & & & & & $0, \mathrm{~V}$ & BA \\
\hline & Nyctidromus albicollis & FG & I & & & & & FCF02176 & $0, \mathrm{~V}$ & $\mathrm{BA}, \mathrm{MU}, \mathrm{FE}$ \\
\hline
\end{tabular}




\begin{tabular}{|c|c|c|c|c|c|c|c|c|c|c|}
\hline \multirow{2}{*}{ Families } & \multirow{2}{*}{ Species' } & \multirow{2}{*}{\multicolumn{2}{|c|}{ Dep ${ }^{2}$ Guild ${ }^{3}$}} & \multirow{2}{*}{ Bamboo $^{4}$} & \multirow{2}{*}{ Endemism $^{5}$} & \multicolumn{2}{|c|}{ Red list $^{6}$} & \multirow{2}{*}{ Voucher ${ }^{7}$} & \multirow{2}{*}{ Rercording $^{8}$} & \multirow{2}{*}{ Municipality } \\
\hline & & & & & & BR & G & & & \\
\hline & Nyctiphrynus ocellatus & FS & I & & & & & FCF02244, AC-972 & $0, \mathrm{~V}, \mathrm{MN}, \mathrm{C}$ & $\mathrm{BA}, \mathrm{FE}$ \\
\hline \multirow[t]{6}{*}{ Apodidae } & Chaetura brachyura & $\mathrm{FG}$ & I & & & & & WA2966613 & $0, \mathrm{~V}$ & $B A, M U, F E$ \\
\hline & Chaetura cinereiventris & $\mathrm{FG}$ & I & & & & & FCF01656, FCF02222 & $0, \mathrm{~V}$ & $B A, M U, F E$ \\
\hline & Chaetura egregia & FS & I & & & & & FCF02138, WA2966616 & $0, \mathrm{~V}$ & BA \\
\hline & Chaetura viridipennis & FS & I & & & & & FCF02139, WA2446773 & $0, \mathrm{~V}$ & $\mathrm{BA}, \mathrm{FE}$ \\
\hline & Panyptila cayennensis & FS & I & & & & & & $0, V$ & $\mathrm{BA}, \mathrm{FE}$ \\
\hline & Tachornis squamata & $\mathrm{NF}$ & I & & & & & & MN & $\mathrm{FE}$ \\
\hline \multirow[t]{14}{*}{ Trochilidae } & Amazilia lactea bartletti & FS & N & & AMS (Inamb) & & & FCF02211, WA2453560 & $0, \mathrm{~V}$ & $B A$ \\
\hline & Anthracothorax nigricollis & $\mathrm{FG}$ & N & & & & & & $0, \mathrm{~V}$ & $\mathrm{BA}$ \\
\hline & Chlorostilbon mellisugus & $\mathrm{FG}$ & N & & & & & FCF01657 & $0, V$ & $\mathrm{BA}, \mathrm{FE}$ \\
\hline & Chrysuronia oenone & FS & $\mathrm{N}$ & & & & & & 0 & $B A, M U$ \\
\hline & Florisuga mellivora & FS & $\mathrm{N}$ & & & & & & 0 & BA \\
\hline & Glaucis hirsutus & FS & $\mathrm{N}$ & & & & & WA2973502, AC-973 & $0, \mathrm{~V}, \mathrm{MN}, \mathrm{C}$ & $B A, M U, P A, F E$ \\
\hline & Heliodoxa aurescens & FS & $\mathrm{N}$ & & & & & & $0, \mathrm{~V}$ & BA \\
\hline & Heliomaster Iongirostris & FS & $\mathrm{N}$ & & & & & WA2446770 & $0, \mathrm{~V}$ & BA \\
\hline & Phaethornis bourcieri & FS & $\mathrm{N}$ & & & & & FCF02248, WA2960614, AC-930, 960, 974 & $0, \mathrm{~V}, \mathrm{MN}, \mathrm{C}$ & $\mathrm{PA}, \mathrm{FE}$ \\
\hline & Phaethornis hispidus & FS & N & & & & & FCF02179, WA2969462, AC-931 & $0, \mathrm{~V}, \mathrm{MN}, \mathrm{C}$ & $B A, M U, P A, F E$ \\
\hline & Phaethornis malaris & FS & $\mathrm{N}$ & & & & & & $0, \mathrm{~V}$ & $B A, P A, F E$ \\
\hline & Phaethornis ruber & FS & N & & & & & FCF02249 & $0, \mathrm{~V}, \mathrm{MN}$ & $\mathrm{BA}, \mathrm{PA}, \mathrm{FE}$ \\
\hline & Thalurania furcata & FG & $\mathrm{N}$ & & & & & WA3484851 & 0 & $\mathrm{BA}, \mathrm{FE}$ \\
\hline & Threnetes leucurus & FS & N & & & & & FCF01764, WA2961269, AC-932 & $0, \mathrm{~V}, \mathrm{MN}, \mathrm{C}$ & $\mathrm{BA}, \mathrm{PA}, \mathrm{FE}$ \\
\hline \multirow[t]{6}{*}{ Trogonidae } & Trogon collaris & FS & 0 & & & & & WA2960594 & $0, \mathrm{~V}$ & $B A, P A$ \\
\hline & Trogon curucui & FS & 0 & & & & & FCF02263, WA2974471 & $0, \mathrm{~V}$ & $\mathrm{BA}, \mathrm{PA}, \mathrm{MU}, \mathrm{FE}$ \\
\hline & Trogon melanurus & FS & 0 & & & & & & $0, \mathrm{~V}$ & $\mathrm{BA}, \mathrm{PA}, \mathrm{FE}$ \\
\hline & Trogon ramonianus & FS & 0 & & & & & WA2968823 & $0, \mathrm{~V}$ & $\mathrm{BA}, \mathrm{FE}$ \\
\hline & Trogon rufus & FS & 0 & & & & & XC386032 & V & $\mathrm{FE}$ \\
\hline & Trogon viridis & FS & 0 & & & & & & $0, \mathrm{~V}$ & $B A, P A, F E$ \\
\hline \multirow[t]{4}{*}{ Alcedinidae } & Chloroceryle americana & FG & $P$ & & & & & & $0, \mathrm{~V}$ & $\mathrm{BA}, \mathrm{FE}$ \\
\hline & Chloroceryle amazona & $\mathrm{NF}$ & $P$ & & & & & & 0 & $\mathrm{FE}$ \\
\hline & Chloroceryle inda & FS & $P$ & & & & & & 0 & $\mathrm{FE}$ \\
\hline & Megaceryle torquata & $\mathrm{FG}$ & $\mathrm{p}$ & & & & & & 0 & $B A, F E$ \\
\hline Momotidae & Baryphthengus martii & FS & 0 & & & & & & V & $B A, F E$ \\
\hline & Electron platyrhynchum & FS & 0 & & & & & FCF02151, WA2973501 & $0, \mathrm{~V}$ & $B A, P A$ \\
\hline & Momotus momota & FS & 0 & & & & & FCF02167, AC-962 & $\mathrm{V}, \mathrm{MN}, \mathrm{C}$ & $\mathrm{BA}, \mathrm{PA}, \mathrm{FE}$ \\
\hline Galbulidae & Galbalcyrhynchus purusianus & FS & I & & AMS (Inamb) & & & FCF01685, WA2972491, WA2474264 & $0, \mathrm{~V}$ & $\mathrm{BA}, \mathrm{MU}, \mathrm{FE}$ \\
\hline & Galbula cyanescens & FS & 1 & & AMS (Inamb) & & & FCF01686 / WA2974473 & $0, \mathrm{~V}, \mathrm{MN}$ & $\mathrm{BA}, \mathrm{PA}, \mathrm{FE}$ \\
\hline & Galbula dea & FS & 1 & & & & & WA2446771 & 0 & BA \\
\hline & Jacamerops aureus & FS & I & & & & & FCF02157 & $0, V$ & $\mathrm{BA}, \mathrm{PA}, \mathrm{FE}$ \\
\hline Bucconidae & Bucco macrodactylus & FS & I & & & & & FCF02216 / WA3187712 & V & $\mathrm{BA}, \mathrm{MU}, \mathrm{FE}$ \\
\hline & Bucco capensis & FS & 1 & & & & & & 0 & $\mathrm{FE}$ \\
\hline & Chelidoptera tenebrosa & FG & 1 & & & & & & $0, V$ & $\mathrm{BA}, \mathrm{FE}$ \\
\hline & Malacoptila semicincta & FS & 1 & & AMS (Inamb) & & & & 0 & $B A$ \\
\hline & Monasa flavirostris & FS & I & & & & & FCF01714, WA2974475 & $0, V$ & $B A, P A$ \\
\hline & Monasa morphoeus & FS & I & & & & & WA2965233 & $0, \mathrm{~V}$ & $\mathrm{BA}, \mathrm{FE}$ \\
\hline & Monasa nigrifrons & FS & 1 & & & & & FCF01715, WA2445540 & $0, \mathrm{~V}$ & $\mathrm{BA}, \mathrm{FE}$ \\
\hline & Nonnula sclateri & FS & I & $\mathrm{x}$ & AMS (Inamb) & & & & $0, \mathrm{MN}$ & $\mathrm{FE}$ \\
\hline & Nonnula ruficapilla ruficapilla & FS & I & $\mathrm{x}$ & AMS (Inamb) & & & FCF02174, AC-940 & $\mathrm{V}, \mathrm{MN}, \mathrm{C}$ & $\mathrm{BA}, \mathrm{FE}$ \\
\hline & Notharchus hyperrhynchus & FS & 1 & & & & & WA2455221 & 0 & $B A$ \\
\hline & Notharchus tectus & FS & I & & & & & & 0 & BA \\
\hline & Nystalus obamai & FS & 1 & & & & & FCF01728, WA2966606 & $0, \mathrm{~V}$ & $B A, P A$ \\
\hline Capitonidae & Capito auratus & FS & 0 & & & & & FCF01653, WA2973500, AC-963 & $0, \mathrm{~V}, \mathrm{MN}, \mathrm{C}$ & $\mathrm{BA}, \mathrm{FE}$ \\
\hline & Eubucco richardsoni & FS & 0 & & & & & FCF01677, WA2974474 & $0, \mathrm{~V}$ & $B A, P A$ \\
\hline Ramphastidae & Aulacorhynchus atrogularis & FS & 0 & & & & & FCF02129, WA2969457 & $0, V$ & $\mathrm{BA}, \mathrm{FE}$ \\
\hline & Pteroglossus beauharnaesii & FS & 0 & & AMS & & & & 0 & BA \\
\hline & Pteroglossus castanotis & FS & 0 & & & & & FCF01745 & $0, \mathrm{~V}$ & $\mathrm{BA}, \mathrm{PA}, \mathrm{FE}$ \\
\hline & Pteroglossus inscriptus & FS & 0 & & & & & FCF02187 & $0, V$ & BA \\
\hline & Ramphastos tucanus cuvieri & FS & 0 & & & & VU & WA2967594 & $0, \mathrm{~V}$ & $\mathrm{BA}, \mathrm{PA}, \mathrm{FE}$ \\
\hline & Ramphastos vitellinus culminatus & FS & 0 & & & & VU & WA3188466 & $0, \mathrm{~V}, \mathrm{MN}$ & $\mathrm{BA}, \mathrm{MU}, \mathrm{PA}, \mathrm{FE}$ \\
\hline & Selenidera reinwardtii Iangsdorffii & FS & 0 & & AMS (Inamb) & & & & V & $B A, P A, F E$ \\
\hline
\end{tabular}




\begin{tabular}{|c|c|c|c|c|c|c|c|c|c|c|}
\hline \multirow{2}{*}{ Families } & \multirow{2}{*}{ Species $^{1}$} & \multirow{2}{*}{$\operatorname{Dep}^{2}$} & \multirow{2}{*}{ Guild $^{3}$} & \multirow{2}{*}{ Bamboo $^{4}$} & \multirow{2}{*}{ Endemism ${ }^{5}$} & \multicolumn{2}{|c|}{ Red list $^{6}$} & \multirow{2}{*}{ Voucher $^{7}$} & \multirow{2}{*}{ Rercording $^{8}$} & \multirow{2}{*}{ Municipality } \\
\hline & & & & & & BR & G & & & \\
\hline \multirow[t]{17}{*}{ Picidae } & Campephilus melanoleucos & FS & I & & & & & FCF02132 & $0, \mathrm{~V}$ & $\mathrm{BA}, \mathrm{PA}, \mathrm{FE}$ \\
\hline & Campephilus rubricollis & FS & I & & & & & FCF01651, WA2966612 & $0, \mathrm{~V}$ & $B A, P A$ \\
\hline & Celeus elegans & FS & I & & & & & FCF02220, WA2617188 & $0, \mathrm{~V}$ & $\mathrm{BA}, \mathrm{PA}, \mathrm{FE}$ \\
\hline & Celeus flavus & FS & 0 & & & & & & $0, \mathrm{~V}$ & $B A$ \\
\hline & Celeus grammicus & FS & I & & & & & & 0 & $B A$ \\
\hline & Celeus spectabilis & FS & I & $x$ & AMS (AF) & & & FCF01654, WA2453569 & $0, \mathrm{~V}$ & $\mathrm{BA}, \mathrm{FE}$ \\
\hline & Celeus torquatus & FS & 0 & & & & & FCF01655, WA2455217 & $0, \mathrm{~V}$ & $\mathrm{BA}, \mathrm{PA}, \mathrm{FE}$ \\
\hline & Colaptes punctigula & FG & I & & & & & FCF01660 & $0, \mathrm{~V}$ & $\mathrm{BA}, \mathrm{FE}$ \\
\hline & Dryocopus lineatus & FG & I & & & & & & $0, \mathrm{~V}$ & $\mathrm{BA}, \mathrm{MU}, \mathrm{FE}$ \\
\hline & Melanerpes cruentatus & FG & I & & & & & WA3484855 & $0, \mathrm{~V}$ & $B A, M U, P A, F E$ \\
\hline & Piculus flavigula & FS & I & & & & & & V & BA \\
\hline & Piculus laemostictus & FS & I & & & & & WA2973496 & $0, \mathrm{~V}$ & $B A$ \\
\hline & Piculus leucolaemus & FS & I & & & $\mathrm{DD}$ & & WA2616184 & $0, \mathrm{~V}$ & $B A$ \\
\hline & Picumnus rufiventris & FS & I & $x$ & & & & FCF01737 & $0, \mathrm{~V}$ & $\mathrm{BA}, \mathrm{FE}$ \\
\hline & Picumnus subtilis & FS & I & $x$ & AMS (AF) & & & WA2849280 & $0, V$ & MU, FE \\
\hline & Veniliornis affinis & FS & I & & & & & & 0 & $\mathrm{BA}, \mathrm{FE}$ \\
\hline & Veniliornis passerinus & FG & I & & & & & FCF02265 & $0, \mathrm{~V}$ & $B A, P A$ \\
\hline \multirow[t]{11}{*}{ Falconidae } & Daptrius ater & FS & 0 & & & & & WA2584161 & $0, \mathrm{~V}$ & $\mathrm{BA}, \mathrm{MU}, \mathrm{FE}$ \\
\hline & Caracara plancus & NF & $C$ & & & & & & 0 & MU, FE \\
\hline & Falco deiroleucus & FS & $C$ & & & & NT & WA2455971 & 0 & $\mathrm{MU}$ \\
\hline & Falco rufigularis & FS & $C$ & & & & & & 0 & $\mathrm{BA}, \mathrm{FE}$ \\
\hline & Herpetotheres cachinnans & $\mathrm{FG}$ & $C$ & & & & & & $0, \mathrm{~V}$ & $\mathrm{BA}, \mathrm{MU}, \mathrm{FE}$ \\
\hline & Ibycter americanus & FS & 0 & & & & & FCF01704, WA2961264 & $0, \mathrm{~V}$ & BA \\
\hline & Micrastur buckleyi & FS & $C$ & & & & & & V & MU \\
\hline & Micrastur gilvicollis & FS & $C$ & & & & & FCF02161-2164, AC-929 & $\mathrm{V}, \mathrm{MN}, \mathrm{C}$ & $\mathrm{BA}, \mathrm{FE}$ \\
\hline & Micrastur mirandollei & FS & $C$ & & & & & & V & $P A$ \\
\hline & Micrastur ruficollis & FS & $C$ & & & & & FCF02165 & V & $B A, M U, P A$ \\
\hline & Micrastur semitorquatus & $\mathrm{FG}$ & $C$ & & & & & & V & BA \\
\hline \multirow[t]{20}{*}{ Psittacidae } & Amazona farinosa & FS & $\mathrm{F}$ & & & & NT & FCF01635-1636 & $0, \mathrm{~V}$ & $\mathrm{BA}, \mathrm{PA}, \mathrm{FE}$ \\
\hline & Amazona ochrocephala & FG & $\mathrm{F}$ & & & & & FCF01637-1638, WA2967596 & $0, \mathrm{~V}$ & $B A, M U, P A, F E$ \\
\hline & Ara ararauna & FG & $\mathrm{F}$ & & & & & WA2455991 & $0, \mathrm{~V}$ & $\mathrm{BA}, \mathrm{FE}$ \\
\hline & Ara chloropterus & FS & $\mathrm{F}$ & & & NT & & WA3208314 & $0, \mathrm{~V}$ & $\mathrm{BA}, \mathrm{MU}$ \\
\hline & Aramacao & FS & $\mathrm{F}$ & & & & & FCF01643, WA2973498 & $0, \mathrm{~V}$ & $B A, M U, P A, F E$ \\
\hline & Ara severus & FG & $\mathrm{F}$ & & & & & WA2455970 & $0, \mathrm{~V}$ & BA \\
\hline & Aratinga weddellii & FG & $\mathrm{F}$ & & & & & FCF01644, WA2455219 & $0, \mathrm{~V}$ & $\mathrm{BA}, \mathrm{MU}, \mathrm{PA}, \mathrm{FE}$ \\
\hline & Brotogeris cyanoptera & FS & $\mathrm{F}$ & & & & & FCF01649, WA2972497 & $0, \mathrm{~V}$ & $B A, M U, P A, F E$ \\
\hline & Brotogeris sanctithomae & FS & $\mathrm{F}$ & & & & & & V & $\mathrm{BA}, \mathrm{MU}$ \\
\hline & Forpus sclateri & FS & $\mathrm{F}$ & & & & & & $0, \mathrm{~V}$ & $\mathrm{BA}, \mathrm{FE}$ \\
\hline & Forpus xanthopterygius & NF & $\mathrm{F}$ & & & & & & $0, \mathrm{~V}$ & BA \\
\hline & Nannopsittaca dachilleae & FS & G & $x$ & AMS (Inamb) & & NT & WA2961270 & 0 & $\mathrm{PA}$ \\
\hline & Orthopsittaca manilatus & FG & $\mathrm{F}$ & & & & & & $0, \mathrm{~V}$ & BA \\
\hline & Pionites leucogaster & FS & $\mathrm{F}$ & & AMS & & & FCF01738, WA2455222 & $0, \mathrm{~V}$ & $\mathrm{FE}$ \\
\hline & Pionus menstruus & FS & $\mathrm{F}$ & & & & & & $0, \mathrm{~V}$ & $B A, P A, F E$ \\
\hline & Primolius couloni & FS & $\mathrm{F}$ & & AMS (Inamb) & & VU & FCF01742, WA2453557 & $0, \mathrm{~V}$ & $\mathrm{BA}, \mathrm{FE}$ \\
\hline & Psittacara leucophthalmus & FG & $\mathrm{F}$ & & & & & FCF01744, WA2965239 & $0, \mathrm{~V}$ & $\mathrm{BA}, \mathrm{MU}, \mathrm{PA}, \mathrm{FE}$ \\
\hline & Pyrilia barrabandi & FS & $\mathrm{F}$ & & & & NT & WA2969464 & 0 & PA \\
\hline & Pyrrhura rupicola & FS & $\mathrm{F}$ & & AMS (Inamb) & & NT & FCF01746, WA2972492 & $0, \mathrm{~V}$ & $\mathrm{BA}, \mathrm{MU}, \mathrm{FE}$ \\
\hline & Touit sp. & FS & $\mathrm{F}$ & & & & & & 0 & $\mathrm{BA}$ \\
\hline Thamnophilidae & Akletos goeldii & FS & I & $x$ & AMS (Inamb) & & & FCF02209-2210 & $0, \mathrm{~V}, \mathrm{MN}$ & $B A, P A, M U, F E$ \\
\hline & Cercomacra cinerascens & FS & I & & & & & & V & $B A, M U, P A, F E$ \\
\hline & Cercomacra manu & FS & I & $x$ & & & & & V & BA \\
\hline & Cercomacra serva & FS & I & & & & & FCF02221, WA2960591 & $0, \mathrm{~V}$ & $B A, P A, F E$ \\
\hline & Cercomacroides fuscicauda & FS & I & & AMS & & & FCF02137 & $0, \mathrm{~V}$ & $\mathrm{BA}, \mathrm{MU}, \mathrm{FE}$ \\
\hline & Cymbilaimus lineatus & FS & 1 & & & & & FCF01669, FCF02146 & $0, \mathrm{~V}$ & $B A, M U, P A$ \\
\hline & Cymbilaimus sanctaemariae & FS & 1 & $x$ & AMS & & & FCF01670-1671, WA2455225 & $0, V$ & $\mathrm{BA}, \mathrm{MU}, \mathrm{FE}$ \\
\hline & Epinecrophylla leucophthalma & FS & I & & & & & FCF01674, WA2969459, AC-927, 935 & $0, \mathrm{~V}, \mathrm{MN}, \mathrm{C}$ & $B A, P A, F E$ \\
\hline & Epinecrophylla ornata & FS & 1 & $x$ & & & & FCF01675, AC-941, 942, 956, 971 & $0, \mathrm{~V}, \mathrm{MN}, \mathrm{C}$ & $\mathrm{BA}, \mathrm{FE}$ \\
\hline & Euchrepomis humeralis & FS & 1 & & & & & FCF02152, WA2631121 & $0, \mathrm{~V}$ & $P A$ \\
\hline & Hafferia fortis & FS & 1 & & & & & FCF01718, FCF01771 & V & $B A, F E$ \\
\hline
\end{tabular}




\begin{tabular}{|c|c|c|c|c|c|c|c|c|c|c|}
\hline \multirow{2}{*}{ Families } & \multirow{2}{*}{ Species $^{1}$} & \multirow{2}{*}{ Dep $^{2}$} & \multirow{2}{*}{ Guild $^{3}$} & \multirow{2}{*}{ Bamboo $^{4}$} & \multirow{2}{*}{ Endemism ${ }^{5}$} & \multicolumn{2}{|c|}{ Red list $^{6}$} & \multirow{2}{*}{ Voucher $^{7}$} & \multirow{2}{*}{ Rercording $^{8}$} & \multirow{2}{*}{ Municipality } \\
\hline & & & & & & BR & G & & & \\
\hline & Hylophylax naevius & FS & 1 & & & & & FCF01702, FCF02230, AC-967, 970 & $0, \mathrm{~V}, \mathrm{MN}, \mathrm{C}$ & $\mathrm{BA}, \mathrm{PA}, \mathrm{FE}$ \\
\hline & Hypocnemis subflava & FS & 1 & $x$ & AMS (Inamb) & & & FCF01703, WA2972494, AC-937, 943, 944, 975 & $0, \mathrm{~V}, \mathrm{MN}, \mathrm{C}$ & $\mathrm{BA}, \mathrm{MU}, \mathrm{PA}, \mathrm{FE}$ \\
\hline & Isleria hauxwelli & FS & 1 & & & & & WA2445541 & $0, \mathrm{MN}$ & $\mathrm{BA}, \mathrm{FE}$ \\
\hline & Microrhopias quixensis & FS & 1 & $x$ & & & & FCF01713, FCF02166, WA2904869 & $0, \mathrm{~V}$ & $\mathrm{BA}, \mathrm{MU}, \mathrm{PA}$ \\
\hline & Myrmelastes humaythae & FS & I & & AMS & & & FCF02169 & V & $\mathrm{BA}, \mathrm{FE}$ \\
\hline & Myrmelastes hyperythrus & FS & 1 & & & & & FCF01719-1720, WA2445538 & $0, \mathrm{~V}$ & BA, MU, FE \\
\hline & Myrmoborus leucophrys & FS & 1 & & & & & FCF01721, WA2972496 & $0, \mathrm{~V}, \mathrm{MN}$ & $B A, M U, P A, F E$ \\
\hline & Myrmoborus lophotes & FS & I & $x$ & AMS (Inamb) & & NT & FCF01722 & $0, \mathrm{~V}, \mathrm{MN}$ & BA \\
\hline & Myrmoborus myotherinus & FS & 1 & & & & & FCF01723, AC-957, 969 & $0, \mathrm{~V}, \mathrm{MN}, \mathrm{C}$ & $\mathrm{BA}, \mathrm{MU}, \mathrm{PA}, \mathrm{FE}$ \\
\hline & Myrmophylax atrothorax & FS & 1 & & & & & FCF01724 & $0, \mathrm{~V}$ & $\mathrm{BA}, \mathrm{MU}, \mathrm{FE}$ \\
\hline & Myrmotherula axillaris & FS & 1 & & & & & WA2960596, AC-955, 966 & $0, \mathrm{~V}, \mathrm{MN}, \mathrm{C}$ & $\mathrm{BA}, \mathrm{PA}, \mathrm{FE}$ \\
\hline & Myrmotherula brachyura & FS & 1 & & & & & FCF01725-1727, WA2969458 & $0, \mathrm{~V}$ & $\mathrm{BA}, \mathrm{MU}, \mathrm{PA}$ \\
\hline & Myrmotherula longipennis & FS & 1 & & & & & AC- $926,933,934$ & $\mathrm{~V}, \mathrm{MN}, \mathrm{C}$ & $B A, P A, F E$ \\
\hline & Myrmotherula menetriesii & FS & I & & & & & FCF02172-2173, WA2966615 & $0, \mathrm{~V}$ & $\mathrm{BA}, \mathrm{PA}, \mathrm{FE}$ \\
\hline & Myrmotherula multostriata & FS & 1 & & & & & & V & BA \\
\hline & Myrmotherula assimilis & FS & 1 & & & & & AC-936 & $\mathrm{MN}, \mathrm{C}$ & $\mathrm{FE}$ \\
\hline & Neoctantes niger & FS & 1 & & & & & & V & $\mathrm{BA}$ \\
\hline & Oneilornis salvini & FS & 1 & & AMS (Inamb) & & & & $0, \mathrm{~V}, \mathrm{MN}$ & $\mathrm{PA}, \mathrm{FE}$ \\
\hline & Phlegopsis nigromaculata & FS & 1 & & & & & FCF01734-1735, WA2965234 & $0, \mathrm{~V}, \mathrm{MN}$ & $\mathrm{BA}, \mathrm{PA}, \mathrm{FE}$ \\
\hline & Sciaphylax hemimelaena & FS & I & & & & & FCF01757, WA2974480 & $0, \mathrm{~V}, \mathrm{MN}$ & $\mathrm{BA}, \mathrm{MU}, \mathrm{PA}, \mathrm{FE}$ \\
\hline & Taraba major & FG & 1 & & & & & FCF01761-1762, AC-964 & $0, \mathrm{~V}, \mathrm{MN}, \mathrm{C}$ & BA, MU, FE \\
\hline & Thamnomanes ardesiacus & FS & 1 & & & & & & V, MN & $\mathrm{BA}, \mathrm{PA}, \mathrm{FE}$ \\
\hline & Thamnomanes saturninus & FS & 1 & & AMS & & & & V & BA \\
\hline & Thamnomanes schistogynus & FS & I & & AMS (Inamb) & & & FCF02198-2200, WA3155295 & $0, V$ & $\mathrm{BA}, \mathrm{MU}, \mathrm{PA}, \mathrm{FE}$ \\
\hline & Thamnophilus aethiops & FS & 1 & & & & & FCF02705 & V & $\mathrm{BA}, \mathrm{PA}, \mathrm{FE}$ \\
\hline & Thamnophilus doliatus & FG & 1 & & & & & & $0, V$ & $\mathrm{BA}, \mathrm{FE}$ \\
\hline & Thamnophilus murinus & FS & 1 & & & & & & V & $B A, P A$ \\
\hline & Thamnophilus schistaceus & FS & 1 & & & & & FCF02259, WA2960597 & $0, V$ & $B A, P A$ \\
\hline & Dichrozona cincta & FS & 1 & & & & & & V & $\mathrm{FE}$ \\
\hline & Willisornis poecilinotus & FS & I & & & & & FCF01000 & $0, \mathrm{~V}, \mathrm{MN}$ & $\mathrm{BA}, \mathrm{PA}, \mathrm{FE}$ \\
\hline \multirow[t]{3}{*}{ Grallariidae } & Grallaria eludens & FS & 1 & & AMS (Inamb) & & & FCF01687 & V & $\mathrm{BA}, \mathrm{PA}$ \\
\hline & Hylopezus berlepschi & FS & I & & & & & FCF01697 & V & $\mathrm{BA}, \mathrm{PA}, \mathrm{FE}$ \\
\hline & Myrmothera campanisona & FS & I & & & & & FCF01691 & V & $B A, P A$ \\
\hline Rhinocryptidae & Liosceles thoracicus & FS & 1 & & & & & FCF01709 & $0, \mathrm{~V}$ & $\mathrm{BA}, \mathrm{PA}, \mathrm{FE}$ \\
\hline \multirow[t]{3}{*}{ Formicariidae } & Formicarius analis & FS & I & & & & & FCF01680 & $0, \mathrm{~V}, \mathrm{MN}$ & $\mathrm{BA}, \mathrm{PA}, \mathrm{FE}$ \\
\hline & Formicarius colma & FS & 1 & & & & & FCF01682 & $\mathrm{V}, \mathrm{MN}$ & $\mathrm{BA}, \mathrm{FE}$ \\
\hline & Formicarius rufifrons & FS & 1 & & AMS (AF) & & NT & FCF01683 & V & $\mathrm{BA}$ \\
\hline \multirow[t]{2}{*}{ Scleruridae } & Sclerurus macconnelli & FS & I & & & & & & $0, \mathrm{MN}$ & $\mathrm{FE}$ \\
\hline & Sclerurus caudacutus & FS & I & & & & & & $0, \mathrm{MN}$ & FE \\
\hline Dendrocolaptidae & Campylorhamphus trochilirostris & FS & 1 & $x$ & & & & FCF01652 & $0, \mathrm{~V}$ & $\mathrm{BA}, \mathrm{PA}, \mathrm{FE}$ \\
\hline & Certhiasomus stictolaema & FS & I & & & & & & V & PA \\
\hline & Deconychura longicauda & FS & 1 & & & & & & $0, V$ & BA \\
\hline & Dendrexetastes rufigula & FS & 1 & & & & & FCF01673, WA2965227 & $0, \mathrm{~V}$ & $\mathrm{BA}$ \\
\hline & Dendrocincla fuliginosa & FS & I & & & & & & $0, \mathrm{MN}$ & $\mathrm{BA}, \mathrm{FE}$ \\
\hline & Dendrocincla merula & FS & 1 & & & & & & MN & FE \\
\hline & Glyphorynchus spirurus castelnaudii & $i \mathrm{FS}$ & 1 & & AMS (AF) & & & & MN & $\mathrm{FE}$ \\
\hline & Dendrocolaptes juruanus & FS & I & & AMS & & & FCF02148, WA2974476 & $0, V$ & $\mathrm{BA}, \mathrm{PA}, \mathrm{FE}$ \\
\hline & Dendrocolaptes picumnus & FS & 1 & & & & & FCF02149 & $0, V$ & $\mathrm{BA}, \mathrm{PA}, \mathrm{FE}$ \\
\hline & Dendroplex picus & FG & 1 & & & & & FCF02295 & $0, V$ & $B A, M U, P A, F E$ \\
\hline & Lepidocolaptes fatimalimae & FS & 1 & & AMS & & & FCF01707, WA2973495 & $0, V$ & $\mathrm{BA}, \mathrm{PA}, \mathrm{FE}$ \\
\hline & Nasica longirostris & FS & 1 & & & & & & $0, V$ & BA \\
\hline & Sittasomus griseicapillus & FS & 1 & & & & & FCF01759 & $0, V$ & $\mathrm{BA}, \mathrm{PA}, \mathrm{FE}$ \\
\hline & Xiphocolaptes promeropirhynchus & FS & 1 & & & & & FCF02266, WA2969465 & $0, \mathrm{~V}$ & BA \\
\hline & Xiphorhynchus elegans & FS & I & & & & & FCF01004 & $0, \mathrm{~V} \cdot \mathrm{MN}$ & $\mathrm{BA}, \mathrm{MU}, \mathrm{PA}, \mathrm{FE}$ \\
\hline & Xiphorhynchus chunchotambo & FS & 1 & & AMS (AF) & & & FCF02707 & V & BA \\
\hline & Xiphorhynchus guttatoides & FS & I & & & & & FCF01001, WA2967601 & $0, \mathrm{~V}, \mathrm{MN}$ & $\mathrm{BA}, \mathrm{PA}, \mathrm{FE}$ \\
\hline Xenopidae & Xenops minutus & FS & 1 & & & & & & $\mathrm{~V}, \mathrm{MN}$ & $\mathrm{BA}, \mathrm{FE}$ \\
\hline & Xenops rutilans & FS & I & & & & & WA3484857 & $0, \mathrm{~V}$ & $\mathrm{BA}, \mathrm{PA}$ \\
\hline Furnariidae & Anabazenops dorsalis & FS & 1 & $x$ & & & & FCF01639 & $0, \mathrm{~V}$ & $B A, M U, P A, F E$ \\
\hline
\end{tabular}




\begin{tabular}{|c|c|c|c|c|c|c|c|c|c|c|}
\hline \multirow{2}{*}{ Families } & \multirow{2}{*}{ Species $^{1}$} & \multirow{2}{*}{ Dep $^{2}$} & \multirow{2}{*}{ Guild $^{3}$} & \multirow{2}{*}{ Bamboo $^{4}$} & \multirow{2}{*}{ Endemism ${ }^{5}$} & \multicolumn{2}{|c|}{ Red list $^{6}$} & \multirow{2}{*}{ Voucher $^{7}$} & \multirow{2}{*}{ Rercording $^{8}$} & \multirow{2}{*}{ Municipality } \\
\hline & & & & & & BR & G & & & \\
\hline & Ancistrops strigilatus & FS & 1 & & & & & FCF02212 & $0, V$ & $B A, P A$ \\
\hline & Automolus infuscatus & FS & 1 & & & & & FCF01647 & V & $\mathrm{BA}, \mathrm{PA}$ \\
\hline & Automolus melanopezus & FS & I & $x$ & & & & FCF01648 & V & $B A$ \\
\hline & Automolus ochrolaemus & FS & 1 & & & & & FCF02131 & $0, \mathrm{~V}, \mathrm{MN}$ & $\mathrm{BA}, \mathrm{PA}, \mathrm{FE}$ \\
\hline & Automolus rufipileatus & FS & 1 & & & & & AC-947, 949 & $\mathrm{~V}, \mathrm{C}, \mathrm{MN}$ & $\mathrm{BA}, \mathrm{FE}$ \\
\hline & Automolus subulatus & FS & 1 & & & & & FCF01696, WA2968822 & $0, \mathrm{~V}$ & $\mathrm{BA}, \mathrm{PA}, \mathrm{FE}$ \\
\hline & Clibanornis watkinsi & FS & 1 & $x$ & AMS (Inamb) & & & FCF01658 & V & $\mathrm{BA}$ \\
\hline & Cranioleuca gutturata & FS & I & & & & & & $0, V$ & $\mathrm{BA}$ \\
\hline & Furnarius leucopus & FG & I & & & & & FCF01684, AC-965 & $0, \mathrm{~V}, \mathrm{MN}$ & $\mathrm{BA}, \mathrm{MU}, \mathrm{FE}$ \\
\hline & Philydor erythrocercum & FS & 1 & & & & & WA2968818 & $0, \mathrm{~V}$ & $\mathrm{PA}, \mathrm{FE}$ \\
\hline & Philydor erythropterum & FS & 1 & & & & & WA2973497 & $0, \mathrm{~V}$ & $B A, P A, F E$ \\
\hline & Synallaxis cherriei & FS & 1 & $x$ & & & NT & FCF02194, AC-939 & $\mathrm{V}, \mathrm{MN}, \mathrm{C}$ & $\mathrm{BA}, \mathrm{MU}, \mathrm{FE}$ \\
\hline & Synallaxis gujanensis & FS & 1 & & & & & & V & $B A, F E$ \\
\hline & Syndactyla ucayalae & FS & 1 & $x$ & & $\mathrm{DD}$ & NT & FCF01760, WA3024890 & $0, \mathrm{~V}$ & $B A, P A, F E$ \\
\hline \multirow[t]{5}{*}{ Pipridae } & Dixiphia pipra & FS & $\mathrm{F}$ & & & & & AC- 938 & $\mathrm{~V}, \mathrm{MN}, \mathrm{C}$ & $\mathrm{BA}, \mathrm{FE}$ \\
\hline & Lepidothrix coronata coronata & FS & $\mathrm{F}$ & & & & & & V.MN & BA \\
\hline & Machaeropterus pyrocephalus & FS & $\mathrm{F}$ & & & & & FCF01770 & V & $\mathrm{BA}, \mathrm{FE}$ \\
\hline & Piprafasciicauda & FS & $\mathrm{F}$ & & & & & FCF02250 & $0, \mathrm{~V}, \mathrm{MN}$ & $B A, P A, F E$ \\
\hline & Tyranneutes stolzmanni & FS & $\mathrm{F}$ & & & & & & V & PA \\
\hline \multirow[t]{2}{*}{ Onychorhynchidae } & Onychorhynchus coronatus & FS & 1 & & & & & & $\mathrm{MN}$ & $\mathrm{FE}$ \\
\hline & Terenotriccus erythrurus & FS & I & & & & & & MN & $\mathrm{FE}$ \\
\hline \multirow[t]{10}{*}{ Tityridae } & lodopleura isabellae & FS & $\mathrm{F}$ & & & & & WA2967600 & $0, \mathrm{~V}$ & $B A, P A$ \\
\hline & Pachyramphus castaneus & FS & 0 & & & & & & V & $\mathrm{BA}$ \\
\hline & Pachyramphus marginatus & FS & 0 & & & & & & V & $\mathrm{BA}$ \\
\hline & Pachyramphus minor & FS & 0 & & & & & FCF01729, WA2965228 & $0, V$ & $B A, P A$ \\
\hline & Pachyramphus polychopterus & FG & 0 & & & & & & V & $B A, P A, F E$ \\
\hline & Pachyramphus xanthogenys & FG & 0 & & & & & FCF01730 & V & BA \\
\hline & Schiffornis major & FS & $\mathrm{F}$ & & & & & FCF01755 & $0, V$ & $\mathrm{BA}, \mathrm{MU}$ \\
\hline & Tityra cayana & FS & 0 & & & & & & $0, \mathrm{~V}$ & $\mathrm{BA}, \mathrm{FE}$ \\
\hline & Tityra inquisitor & FS & 0 & & & & & & 0 & $B A$ \\
\hline & Tityra semifasciata & FS & 0 & & & & & FCF01766 & $0, V$ & $B A, F E$ \\
\hline Cotingidae & Conioptilon mcilhennyi & FS & $\mathrm{F}$ & & AMS (Inamb) & & & FCF01661 & $0, \mathrm{~V}$ & $B A, P A, F E$ \\
\hline & Cotinga cayana & FS & $\mathrm{F}$ & & & & & & 0 & $\mathrm{BA}$ \\
\hline & Cotinga maynana & FS & $\mathrm{F}$ & & & & & FCF02224, WA2960588 & $0, \mathrm{~V}$ & $\mathrm{BA}, \mathrm{PA}$ \\
\hline & Gymnoderus foetidus & FS & $\mathrm{F}$ & & & & & WA2969461 & $0, \mathrm{~V}$ & $\mathrm{BA}, \mathrm{FE}$ \\
\hline & Lipaugus vociferans & FS & $\mathrm{F}$ & & & & & & V & $B A, P A$ \\
\hline & Porphyrolaema porphyrolaema & FS & $\mathrm{F}$ & & & & & WA2960587 & 0 & $B A$ \\
\hline & Querula purpurata & FS & $\mathrm{F}$ & & & & & FCF01747 & $0, V$ & $B A, P A, F E$ \\
\hline Pipritidae & Piprites chloris & FS & 1 & & & & & FCF01739 & $0, \mathrm{~V}$ & $B A, P A, F E$ \\
\hline Rhynchocyclidae & Cnipodectes subbrunneus & FS & 1 & & & & & FCF01659 & $0, \mathrm{~V}, \mathrm{MN}$ & $B A, F E$ \\
\hline & Corythopis torquatus & FS & 1 & & & & & FCF02142, WA2969463 & $0, \mathrm{~V}, \mathrm{MN}$ & $\mathrm{PA}, \mathrm{FE}$ \\
\hline & Hemitriccus flammulatus & FS & 1 & $x$ & & & & & $\mathrm{~V}, \mathrm{MN}$ & $\mathrm{BA}, \mathrm{FE}$ \\
\hline & Hemitriccus iohannis & FS & 1 & & & & & FCF01692 & $0, \mathrm{~V}, \mathrm{MN}$ & $\mathrm{BA}, \mathrm{MU}$ \\
\hline & Hemitriccus sp. & & 1 & & & & & & V & $\mathrm{BA}$ \\
\hline & Leptopogon amaurocephalus & FS & 1 & & & & & FCF01708 & V & $\mathrm{BA}, \mathrm{FE}$ \\
\hline & Lophotriccus eulophotes & FS & 1 & $x$ & AMS (Inamb) & & & FCF01711, WA2455230 & $0, \mathrm{~V}, \mathrm{MN}$ & $B A, F E$ \\
\hline & Mionectes oleagineus & FS & 0 & & & & & & $\mathrm{~V}, \mathrm{MN}$ & $\mathrm{PA}, \mathrm{FE}$ \\
\hline & Myiornis ecaudatus & FS & 1 & & & & & & V & $\mathrm{BA}$ \\
\hline & Rhynchocyclus olivaceus & FS & 1 & & & & & FCF02702 & V & $\mathrm{BA}$ \\
\hline & Todirostrum chrysocrotaphum & FS & 1 & & & & & FCF01767 & $0, V$ & $\mathrm{BA}, \mathrm{PA}, \mathrm{FE}$ \\
\hline & Todirostrum maculatum & FG & 1 & & & & & WA2445562 & $0, \mathrm{~V}$ & $\mathrm{BA}, \mathrm{FE}$ \\
\hline & Poecilotriccus latirostris & FS & 1 & & & & & FCF02700 & V & $\mathrm{FE}$ \\
\hline & Tolmomyias assimilis & FS & 1 & & & & & FCF01768 & $0, \mathrm{~V}$ & $\mathrm{BA}, \mathrm{PA}$ \\
\hline & Tolmomyias flaviventris viridiceps & FS & 1 & & & & & WA3484859 & $0, \mathrm{~V}$ & $\mathrm{BA}$ \\
\hline & Tolmomyias poliocephalus & FS & 1 & & & & & FCF00994, AC-945 & $0, \mathrm{~V}, \mathrm{MN}, \mathrm{C}$ & $B A, P A, F E$ \\
\hline & Tolmomyias sulphurescens & FS & 1 & & & & & FCF02262, WA2968820 & $0, \mathrm{~V}$ & $\mathrm{BA}$ \\
\hline Tyrannidae & Attila bolivianus & FS & 1 & & & & & & V & $B A, P A, F E$ \\
\hline & Attila spadiceus & FS & 1 & & & & & FCF01646 & $\mathrm{V}, \mathrm{MN}$ & $\mathrm{BA}, \mathrm{FE}$ \\
\hline & Camptostoma obsoletum & $\mathrm{NF}$ & I & & & & & & $0, \mathrm{~V}$ & $\mathrm{BA}, \mathrm{FE}$ \\
\hline
\end{tabular}




\begin{tabular}{|c|c|c|c|c|c|c|c|c|c|c|}
\hline \multirow{2}{*}{ Families } & \multirow{2}{*}{ Species' } & \multirow{2}{*}{ Dep ${ }^{2}$} & \multirow{2}{*}{ Guild $^{3}$} & \multirow{2}{*}{ Bamboo ${ }^{4}$} & \multirow{2}{*}{ Endemism $^{5}$} & \multicolumn{2}{|c|}{ Red list $^{6}$} & \multirow{2}{*}{ Voucher ${ }^{7}$} & \multirow{2}{*}{ Rercording $^{8}$} & \multirow{2}{*}{ Municipality } \\
\hline & & & & & & BR & G & & & \\
\hline & Colonia colonus & FS & 1 & & & & & FCF02140 & $0, \mathrm{~V}$ & BA \\
\hline & Conopias trivirgatus & FS & 1 & & & & & FCF02141 & $0, \mathrm{~V}$ & BA \\
\hline & Elaenia spectabilis & FS & 0 & & & & & FCF02150, AC-946 & $0, \mathrm{~V}, \mathrm{MN}$ & $\mathrm{BA}, \mathrm{MU}, \mathrm{FE}$ \\
\hline & Elaenia parvirostris & $\mathrm{NF}$ & 0 & & & & & AC-950, 968 & MN, & $\mathrm{FE}$ \\
\hline & Griseotyrannus aurantioatrocristatus & $s$ FG & 1 & & & & & WA2974478 & $0, \mathrm{~V}$ & BA \\
\hline & Lathrotriccus euleri & FS & 1 & & & & & & V & $\mathrm{BA}$ \\
\hline & Legatus leucophaius & $\mathrm{FG}$ & 1 & & & & & FCF02234 & $0, V$ & $B A, P A, F E$ \\
\hline & Megarynchus pitangua & $\mathrm{FG}$ & 0 & & & & & & $0, V$ & $\mathrm{BA}, \mathrm{MU}, \mathrm{FE}$ \\
\hline & Myiarchus ferox & $\mathrm{FG}$ & 0 & & & & & & $0, V$ & $B A, F E$ \\
\hline & Myiarchus tuberculifer & $\mathrm{FG}$ & 1 & & & & & & V & $B A$ \\
\hline & Myiarchus tyrannulus & $\mathrm{FG}$ & 0 & & & & & & V & BA \\
\hline & Myiodynastes maculatus & FS & 0 & & & & & & $0, \mathrm{~V}$ & $\mathrm{BA}, \mathrm{MU}, \mathrm{FE}$ \\
\hline & Myiopagis caniceps & FS & I & & & & & & V & BA \\
\hline & Myiopagis gaimardii & FS & I & & & & & & $0, \mathrm{~V}$ & $\mathrm{BA}, \mathrm{PA}$ \\
\hline & Myiophobus fasciatus & $\mathrm{NF}$ & 1 & & & & & & V & $\mathrm{BA}, \mathrm{FE}$ \\
\hline & Myiozetetes cayanensis & FS & 0 & & & & & FCF02168 & $0, \mathrm{~V}$ & $\mathrm{BA}, \mathrm{MU}, \mathrm{FE}$ \\
\hline & Myiozetetes granadensis & $\mathrm{FG}$ & 0 & & & & & FCF01716, WA2446761 & $0, \mathrm{~V}$ & $\mathrm{BA}, \mathrm{MU}, \mathrm{FE}$ \\
\hline & Myiozetetes luteiventris & FS & 1 & & & & & & V & BA \\
\hline & Myiozetetes similis & $\mathrm{FG}$ & 0 & & & & & & $0, \mathrm{~V}$ & $\mathrm{BA}, \mathrm{FE}$ \\
\hline & Ochthornis littoralis & $\mathrm{NF}$ & 1 & & & & & FCF02246 & $0, V$ & $\mathrm{BA}, \mathrm{MU}$ \\
\hline & Ornithion inerme & FS & 1 & & & & & & V & $\mathrm{BA}, \mathrm{FE}$ \\
\hline & Philohydor lictor & FS & 1 & & & & & FCF01733 & $0, V$ & $\mathrm{BA}, \mathrm{FE}$ \\
\hline & Pitangus sulphuratus & $\mathrm{NF}$ & 0 & & & & & FCF01740 & $0, V$ & $\mathrm{BA}, \mathrm{FE}$ \\
\hline & Pyrocephalus rubinus & $\mathrm{NF}$ & 1 & & & & & & 0 & $\mathrm{BA}, \mathrm{FE}$ \\
\hline & Ramphotrigon fuscicauda & FS & 1 & $x$ & & & & FCF01749, WA2455228, AC-959 & $0, \mathrm{~V}, \mathrm{MN}, \mathrm{C}$ & $\mathrm{BA}, \mathrm{PA}, \mathrm{FE}$ \\
\hline & Ramphotrigon megacephalum & FS & 1 & $x$ & & & & FCF01750 & $0, \mathrm{~V}$ & $\mathrm{BA}, \mathrm{PA}, \mathrm{FE}$ \\
\hline & Ramphotrigon ruficauda & FS & 1 & & & & & & V & $\mathrm{BA}, \mathrm{FE}$ \\
\hline & Rhytipterna simplex & FS & 1 & & & & & FCF02190, WA2973503 & $0, \mathrm{~V}$ & $\mathrm{BA}, \mathrm{PA}, \mathrm{FE}$ \\
\hline & Muscisaxicola fluviatilis & $\mathrm{NF}$ & 1 & & & & & AC-948 & $c$ & $\mathrm{FE}$ \\
\hline & Sirystes albocinereus & FS & 1 & & & & & FCF01758, WA2960595 & $0, \mathrm{~V}$ & $B A, P A, F E$ \\
\hline & Phaeomyias murina & $\mathrm{NF}$ & 0 & & & & & & V & $\mathrm{FE}$ \\
\hline & Sublegatus obscurior & FS & 1 & & & & & WA2445534 & 0 & MU \\
\hline & Tyrannulus elatus & FS & 1 & & & & & & V & $\mathrm{BA}, \mathrm{MU}, \mathrm{FE}$ \\
\hline & Tyrannus albogularis & $\mathrm{NF}$ & 1 & & & & & & 0 & $\mathrm{BA}$ \\
\hline & Tyrannus melancholicus & $\mathrm{NF}$ & 0 & & & & & & $0, V$ & $\mathrm{BA}, \mathrm{MU}, \mathrm{FE}$ \\
\hline & Tyrannus savana & $\mathrm{NF}$ & 1 & & & & & WA2679292 & $0, V$ & $\mathrm{FE}$ \\
\hline & Zimmerius gracilipes & $\mathrm{FG}$ & 1 & & & & & WA2960590 & $0, V$ & $B A, P A$ \\
\hline \multirow[t]{5}{*}{ Vireonidae } & Cyclarhis gujanensis & $\mathrm{FG}$ & 0 & & & & & FCF01667 & V & $\mathrm{BA}, \mathrm{PA}, \mathrm{FE}$ \\
\hline & Hylophilus thoracicus & FS & 1 & & & & & FCF01701 & V & BA \\
\hline & Pachysylvia hypoxantha & FS & 1 & & & & & FCF01700 & V & $B A, P A$ \\
\hline & Vireo chivi & FS & 0 & & & & & & $0, V$ & $B A, P A$ \\
\hline & Vireolanius leucotis & FS & 0 & & & & & & V & $\mathrm{BA}, \mathrm{PA}, \mathrm{FE}$ \\
\hline Corvidae & Cyanocorax violaceus & $\mathrm{FG}$ & 0 & & & & & & $0, \mathrm{~V}$ & $\mathrm{BA}, \mathrm{FE}$ \\
\hline \multirow[t]{5}{*}{ Hirundinidae } & Atticora fasciata & $\mathrm{FG}$ & 1 & & & & & FCF01645 & $0, \mathrm{~V}$ & $\mathrm{BA}, \mathrm{MU}, \mathrm{FE}$ \\
\hline & Progne chalybea & $\mathrm{NF}$ & 1 & & & & & & $0, \mathrm{~V}$ & $\mathrm{BA}, \mathrm{MU}, \mathrm{FE}$ \\
\hline & Prognetapera & $\mathrm{NF}$ & 1 & & & & & & $0, \mathrm{~V}$ & $\mathrm{FE}$ \\
\hline & Stelgidopteryx ruficollis & $\mathrm{NF}$ & 1 & & & & & & $0, \mathrm{~V}$ & $\mathrm{BA}, \mathrm{MU}, \mathrm{FE}$ \\
\hline & Tachycineta albiventer & $\mathrm{NF}$ & 1 & & & & & & $0, \mathrm{~V}$ & $\mathrm{BA}, \mathrm{MU}, \mathrm{FE}$ \\
\hline \multirow[t]{6}{*}{ Troglodytidae } & Campylorhynchus turdinus & FS & 1 & & & & & FCF02218, WA2455989 & $0, V$ & $\mathrm{BA}, \mathrm{MU}, \mathrm{PA}, \mathrm{FE}$ \\
\hline & Cantorchilus leucotis & FS & 1 & & & & & FCF02135 & V & $B A, M U$ \\
\hline & Cyphorhinus arada modulator & FS & 1 & & AMS (Inamb) & & & FCF01672 & V & BA \\
\hline & Microcerculus marginatus & FS & 1 & & & & & & $0, \mathrm{~V}$ & $B A, P A, F E$ \\
\hline & Pheugopedius genibarbis & FS & 1 & & & & & AC-958 & $0, \mathrm{~V}, \mathrm{MN}, \mathrm{C}$ & $\mathrm{BA}, \mathrm{MU}, \mathrm{PA}, \mathrm{FE}$ \\
\hline & Troglodytes musculus & NF & 1 & & & & & FCF02201 & $0, \mathrm{~V}$ & $\mathrm{BA}, \mathrm{MU}, \mathrm{FE}$ \\
\hline Donacobiidae & Donacobius atricapilla & $\mathrm{NF}$ & 1 & & & & & WA3592768 & 0 & $\mathrm{MU}, \mathrm{FE}$ \\
\hline Polioptilidae & Polioptila plumbea & $\mathrm{FG}$ & 1 & & & & & FCF01741, WA2455216 & $0, \mathrm{~V}$ & $B A, M U$ \\
\hline Turdidae & Turdus amaurochalinus & $\mathrm{FG}$ & 0 & & & & & FCF00999 & $0, \mathrm{~V}$ & $B A$ \\
\hline & Turdus hauxwelli & FS & 0 & & & & & FCF02706 & V & PA \\
\hline & Turdus ignobilis & FS & 0 & & & & & WA3484858 & $0, \mathrm{~V}$ & $\mathrm{BA}, \mathrm{FE}$ \\
\hline
\end{tabular}




\begin{tabular}{|c|c|c|c|c|c|c|c|c|c|c|}
\hline \multirow{2}{*}{ Families } & \multirow{2}{*}{ Species $^{1}$} & \multirow{2}{*}{ Dep $^{2}$} & \multirow{2}{*}{ Guild $^{3}$} & \multirow{2}{*}{ Bamboo $^{4}$} & \multirow{2}{*}{ Endemism $^{5}$} & \multicolumn{2}{|c|}{ Red list $^{6}$} & \multirow{2}{*}{ Voucher $^{7}$} & \multirow{2}{*}{ Rercording $^{8}$} & \multirow{2}{*}{ Municipality } \\
\hline & & & & & & BR & G & & & \\
\hline & Turdus albicollis & FS & 0 & & & & & AC-928 & $C$ & $\mathrm{FE}$ \\
\hline Passerelidae & Ammodramus aurifrons & NF & $G$ & & & & & WA2453563 & $0, \mathrm{~V}$ & $\mathrm{BA}, \mathrm{MU}, \mathrm{FE}$ \\
\hline Parulidae & Myiothlypis fulvicauda & FS & 1 & & & & & & 0 & $\mathrm{BA}, \mathrm{FE}$ \\
\hline \multirow[t]{12}{*}{ Icteridae } & Cacicus cela & FS & 0 & & & & & FCF01650 & $0, \mathrm{~V}$ & $B A, M U, P A, F E$ \\
\hline & Cacicus haemorrhous & $\mathrm{FG}$ & 0 & & & & & & V & BA \\
\hline & Icterus cayanensis & FS & 0 & & & & & FCF02232, WA2972498 & $0, \mathrm{~V}$ & BA \\
\hline & Icterus croconotus & $\mathrm{FG}$ & 0 & & & & & FCF01705 & $0, \mathrm{~V}$ & $\mathrm{BA}, \mathrm{FE}$ \\
\hline & Molothrus bonariensis & NF & 0 & & & & & & $0, \mathrm{~V}$ & $\mathrm{BA}$ \\
\hline & Molothrus oryzivorus & NF & 0 & & & & & & 0 & $\mathrm{BA}, \mathrm{FE}$ \\
\hline & Psarocolius angustifrons & FS & 0 & & & & & FCF02184 & $0, \mathrm{~V}$ & MU \\
\hline & Psarocolius bifasciatus & FS & 0 & & & & & FCF01743, WA2455988 & $0, \mathrm{~V}$ & $\mathrm{BA}, \mathrm{FE}$ \\
\hline & Psarocolius decumanus & FS & 0 & & & & & FCF02185 & $0, \mathrm{~V}$ & $\mathrm{BA}, \mathrm{PA}, \mathrm{FE}$ \\
\hline & Psarocolius viridis & FS & 0 & & & & & & 0 & BA \\
\hline & Procacicus solitarius & FG & 0 & & & & & WA2672491 & V & $\mathrm{FE}$ \\
\hline & Sturnella militaris & NF & I & & & & & & $0, \mathrm{~V}$ & $\mathrm{MU}, \mathrm{FE}$ \\
\hline Mitrospingidae & Lamprospiza melanoleuca & FS & $\mathrm{F}$ & & & & & FCF01706 & $0, \mathrm{~V}$ & $\mathrm{BA}, \mathrm{FE}$ \\
\hline \multirow[t]{32}{*}{ Thraupidae } & Chlorophanes spiza & FS & 0 & & & & & & 0 & $B A$ \\
\hline & Cissopis leverianus & FS & 0 & & & & & & $0, \mathrm{~V}$ & $\mathrm{BA}, \mathrm{MU}, \mathrm{FE}$ \\
\hline & Dacnis cayana & FG & 0 & & & & & & 0 & $\mathrm{BA}, \mathrm{FE}$ \\
\hline & Dacnis flaviventris & FS & $\mathrm{F}$ & & & & & & 0 & BA \\
\hline & Dacnis lineata & FS & $\mathrm{F}$ & & & & & WA2965226 & $0, \mathrm{~V}$ & BA \\
\hline & Hemithraupis flavicollis & FS & I & & & & & & $0, \mathrm{~V}$ & $\mathrm{BA}$ \\
\hline & Hemithraupis guira & FS & I & & & & & & $0, \mathrm{~V}$ & $B A$ \\
\hline & Lanio luctuosus & FS & 0 & & & & & WA2972493 & $0, \mathrm{~V}, \mathrm{MN}$ & $\mathrm{BA}, \mathrm{FE}$ \\
\hline & Lanio versicolor & FS & 0 & & AMS & & & FCF02233, WA2961267 & $0, \mathrm{~V}, \mathrm{MN}$ & $\mathrm{PA}, \mathrm{FE}$ \\
\hline & Nemosia pileata & FS & 0 & & & & & WA3208250 & 0 & $\mathrm{BA}, \mathrm{MU}$ \\
\hline & Parkerthraustes humeralis & FS & 0 & & & & & FCF02233, WA2965223 & $0, \mathrm{~V}$ & $B A$ \\
\hline & Paroaria gularis & $\mathrm{FG}$ & 0 & & & & & WA2474270 & 0 & $\mathrm{BA}, \mathrm{MU}, \mathrm{FE}$ \\
\hline & Ramphocelus carbo & FG & 0 & & & & & & $0, \mathrm{~V}, \mathrm{MN}$ & $\mathrm{BA}, \mathrm{MU}, \mathrm{FE}$ \\
\hline & Ramphocelus nigrogularis & FS & 0 & & & & & FCF01748, WA2445536 & $0, V$ & $\mathrm{BA}, \mathrm{MU}, \mathrm{FE}$ \\
\hline & Saltator coerulescens azare & FG & 0 & & & & & & $0, \mathrm{~V}$ & $\mathrm{BA}, \mathrm{MU}, \mathrm{FE}$ \\
\hline & Saltator grossus & FS & 0 & & & & & & $0, \mathrm{~V}$ & BA, PA \\
\hline & Saltator maximus & FS & 0 & & & & & & $0, \mathrm{~V}$ & $\mathrm{BA}, \mathrm{MU}, \mathrm{FE}$ \\
\hline & Sporophila angolensis & NF & $G$ & & & & & & $0, \mathrm{~V}, \mathrm{MN}$ & MU, FE \\
\hline & Sporophila bouvronides & NF & G & & & & & FCF02193, WA2445535 & $0, \mathrm{~V}$ & BA \\
\hline & Sporophila caerulescens & NF & G & & & & & & 0 & $\mathrm{BA}, \mathrm{MU}, \mathrm{FE}$ \\
\hline & Sporophila castaneiventris & NF & G & & & & & & 0 & $\mathrm{BA}, \mathrm{FE}$ \\
\hline & Sporophila lineola & $\mathrm{NF}$ & $G$ & & & & & WA2904900 & 0 & $\mathrm{BA}, \mathrm{MU}$ \\
\hline & Tangara callophrys & FS & $\mathrm{F}$ & & & & & WA2455227 & $0, \mathrm{~V}$ & $\mathrm{BA}, \mathrm{MU}$ \\
\hline & Tangara chilensis & FS & $\mathrm{F}$ & & & & & FCF02255 & $0, \mathrm{~V}$ & $B A, P A, M U, F E$ \\
\hline & Tangara episcopus & FS & $\mathrm{F}$ & & & & & FCF02256 & $0, \mathrm{~V}$ & $\mathrm{BA}, \mathrm{MU}, \mathrm{FE}$ \\
\hline & Tangara mexicana & FS & $\mathrm{F}$ & & & & & FCF02197, WA2967599 & $0, \mathrm{~V}$ & $\mathrm{BA}, \mathrm{MU}$ \\
\hline & Tangara nigrocincta & FS & $\mathrm{F}$ & & & & & FCF02257, WA2961265 & $0, \mathrm{~V}$ & BA \\
\hline & Tangara palmarum & FG & 0 & & & & & & $0, \mathrm{~V}$ & $\mathrm{BA}, \mathrm{MU}, \mathrm{FE}$ \\
\hline & Tangara schrankii & FS & $\mathrm{F}$ & & & & & & $0, \mathrm{MN}$ & $\mathrm{BA}, \mathrm{FE}$ \\
\hline & Tangara velia & FS & $\mathrm{F}$ & & & & & WA3484698 & $0, \mathrm{~V}$ & $\mathrm{BA}, \mathrm{FE}$ \\
\hline & Tersina viridis & FS & $\mathrm{F}$ & & & & & & $0, \mathrm{~V}$ & $B A, P A$ \\
\hline & Volatinia jacarina & NF & $G$ & & & & & & $0, \mathrm{~V} . \mathrm{MN}$ & $\mathrm{BA}, \mathrm{MU}, \mathrm{FE}$ \\
\hline Cardinalidae & Cyanoloxia rothschildii & FS & 0 & & & & & FCF02145, FCF02225 & V & $\mathrm{BA}, \mathrm{PA}, \mathrm{FE}$ \\
\hline \multirow[t]{4}{*}{ Fringillidae } & Euphonia chlorotica & FG & $\mathrm{F}$ & & & & & & V & $\mathrm{FE}$ \\
\hline & Euphonia chrysopasta & FS & $\mathrm{F}$ & & & & & FCF01678, & $0, \mathrm{~V}$ & $\mathrm{BA}, \mathrm{MU}, \mathrm{PA}, \mathrm{FE}$ \\
\hline & Euphonia minuta & FS & $\mathrm{F}$ & & & & & & V & $\mathrm{BA}, \mathrm{PA}$ \\
\hline & Euphonia rufiventris & FS & $\mathrm{F}$ & & & & & WA3484861 & $0, \mathrm{~V}$ & $\mathrm{BA}, \mathrm{PA}, \mathrm{FE}$ \\
\hline
\end{tabular}

